\title{
Nutritional status and muscle dysfunction in chronic respiratory diseases: stable phase versus acute exacerbations
}

\author{
Joaquim Gea, Antoni Sancho-Muñoz, Roberto Chalela \\ Respiratory Medicine Department, Hospital del Mar (IMIM), DCEXS, Universitat Pompeu Fabra, CIBERES, ISCIII, Barcelona, Spain \\ Contributions: (I) Conception and design: J Gea; (II) Administrative support: J Gea; (III) Provision of study materials or patients: All authors; (IV) \\ Collection and assembly of data: All authors; (IV) Data analysis and interpretation: All authors; (VI) Manuscript writing: All authors; (VII) Final \\ approval of manuscript: All authors. \\ Correspondence to: Joaquim Gea. Servei de Pneumologia, Hospital del Mar, Pg. Marítim 27, 08003 Barcelona, Spain. Email: JGea@parcdesalutmar.cat.
}

\begin{abstract}
Nutritional abnormalities are frequent in different chronic respiratory diseases such as chronic obstructive pulmonary disease (COPD), bronchiectasis, cystic fibrosis (CF), interstitial fibrosis and lung cancer, having important clinical consequences. However, nutritional abnormalities often remained underdiagnosed due to the relative lack of awareness of health professionals. Therefore, systematic anthropometry or even better, assessment of body composition, should be performed in all patients with chronic respiratory conditions, especially following exacerbation periods when malnutrition becomes more accentuated. Nutritional abnormalities very often include the loss of muscle mass, which is an important factor for the occurrence of muscle dysfunction. The latter can be easily detected with the specific assessment of muscle strength and endurance, and also negatively influences patients' quality of life and prognosis. Both nutritional abnormalities and muscle dysfunction result from the interaction of several factors, including tobacco smoking, low physical activity-sedentarism, systemic inflammation and the imbalance between energy supply and requirements, which essentially lead to a negative balance between protein breakdown and synthesis. Therapeutic approaches include improvements in lifestyle, nutritional supplementation and training. Anabolic drugs may be administered in some cases.
\end{abstract}

Keywords: Nutritional abnormalities; low body weight; muscle mass; muscle dysfunction; diet; exercise; prognosis; lung diseases

Submitted Nov 02, 2017. Accepted for publication Feb 22, 2018.

doi: $10.21037 /$ jtd.2018.02.66

View this article at: http://dx.doi.org/10.21037/jtd.2018.02.66

\section{Introduction}

Many different and prevalent chronic respiratory disorders, such as chronic obstructive pulmonary disease (COPD), cystic fibrosis (CF), non-CF bronchiectasis, idiopathic pulmonary fibrosis (IPF) and lung cancer, not only target the lungs but are often associated with systemic manifestations (1-5). The latter can be magnified by the concomitant presence of aging, comorbidities or unhealthy lifestyle habits. Nutritional abnormalities stand out amongst the systemic manifestations present in chronic respiratory conditions. When these nutritional abnormalities become very severe, with marked weight and muscle mass loss, they constitute a complex metabolic syndrome, known as cachexia. However, it should be kept in mind that the earliest stages of nutritional abnormalities do not necessarily involve evident body weight loss. Diagnosis and stratification of patients with impaired nutritional status is important to decide the appropriate therapeutic approach. In fact, it has been clearly demonstrated that therapeutic interventions, even with only moderate increases in body weight or lean mass, can improve the prognosis of respiratory patients with nutritional abnormalities (6). Therefore, medical professionals should be able to detect these deficiencies early.

Although the clinical impact of nutritional abnormalities 
has been extensively studied in COPD, similar deleterious effects have also been reported in other chronic respiratory diseases. In the particular case of COPD, impairment in nutritional status has been associated with poor prognosis, deterioration of the quality of life, a higher exacerbation rate and an increased mortality $(6,7)$. Similar negative impact has also been described in other respiratory conditions $(3,8)$, which in addition can be associated with COPD in specific mixed phenotypes (COPD-bronchiectasis, -fibrosis, -asthma) (1).

One of the most important clinical consequences of nutritional deficiencies in patients with chronic respiratory disorders is the loss of muscle mass and functional impairment $(2,4,9)$. However, nutritional deficiencies not only affect muscle mass and function, but can also have a negative impact on bone and fat tissues, reaching a state of severe cachexia in the more advanced situations. Moreover, malnutrition also targets patient's immunocompetence, facilitating infections and exacerbations, which reciprocally will contribute to worsen nutritional status.

Muscle dysfunction is defined by the loss of strength (i.e., the ability to develop a maximal effort) and/or endurance (i.e., the ability to maintain a submaximal effort through time) $(10,11)$. This functional impairment can be relatively stable (this is known as 'muscle weakness') or temporary (denominated 'fatigue', which is reversible with rest) $(10,11)$. Muscle dysfunction can involve peripheral (limb) as well as respiratory muscles, and can appear in acute or chronic respiratory diseases due to different causes. However, the loss of muscle mass is probably the main one, at least for limb muscles, having deleterious consequences on patients' prognosis $(12,13)$. The term 'loss of muscle mass' is generally used to express a decrease in global muscle proportion or weight, but at a cellular level it actually indicates the loss of fibers or more frequently, a reduction in their size. The loss of muscle mass is mainly because of a decrease in muscle contractile protein content through different mechanisms, including the activation of the ubiquitin-proteasome system, autophagy and apoptosis (14). Global muscle mass and fiber size are the main factors contributing to muscle strength, although other components such as fiber type proportions and muscle length also play a relevant role (12). Therefore, a loss in either muscle mass or fiber atrophy will involve a decrease in contractile strength. On the other hand, endurance depends mostly on the muscle aerobic capacity, which in turn is a subrogate of the percentage of fibers with a predominant aerobic metabolism ('slow-twitch' fibers), capillary and mitochondrial density, and the capacity of oxidative enzymes on metabolic pathways (12).

The presence of limb muscle dysfunction can even limit normal walking, leading to a reduction of patient daily activities and social life, with a strong negative impact on prognosis, quality of life, and utilization of social and health resources $(3,7,8,15-18)$. Respiratory muscle dysfunction in turn is associated with increased dyspnea $(10,11,19)$, a worse ventilatory response to both exercise and exacerbations (19-21), and can even lead to severe respiratory failure, as well as weaning difficulties in patients submitted to mechanical ventilation $(22,23)$.

\section{Etiology}

The loss of body weight, as well as that of muscle mass and function is the result of the interaction of different etiological factors, which interestingly have different relative weights for each particular patient. These factors include toxic and lifestyle habits, as well as metabolic and hormonal imbalances (Figure 1).

\section{Smoking and alcobol abuse}

Tobacco has a clear anorectic effect and can induce nutritional abnormalities and muscle dysfunction by different mechanisms, which include systemic inflammation, release of leptin, induction of an imbalance between protein synthesis/breakdown, and the blockade of neuromuscular transmission (24-28). As a consequence of all these phenomena, smokers show early fatigability and reduced muscle resistance $(25,29,30)$. Enolism, frequently associated with smoking (31), can also induce loss of body weight and lean mass as well as a specific myopathy $(32,33)$.

\section{Sedentarism and low level of physical activity}

This factor is very common in chronic respiratory diseases due mainly to ventilatory limitation, muscle dysfunction due to other factors and reactive depression, as well as Western lifestyle (34-36). It contributes to the presence of nutritional abnormalities and muscle dysfunction (especially of the lower limbs) and also results in cardiovascular deconditioning, having a negative impact on exacerbations and mortality (3638). The main molecular mechanisms explaining some of the negative effects of reduced activity are an increase in the level of systemic inflammation and a decrease in muscle protein synthesis (39). 


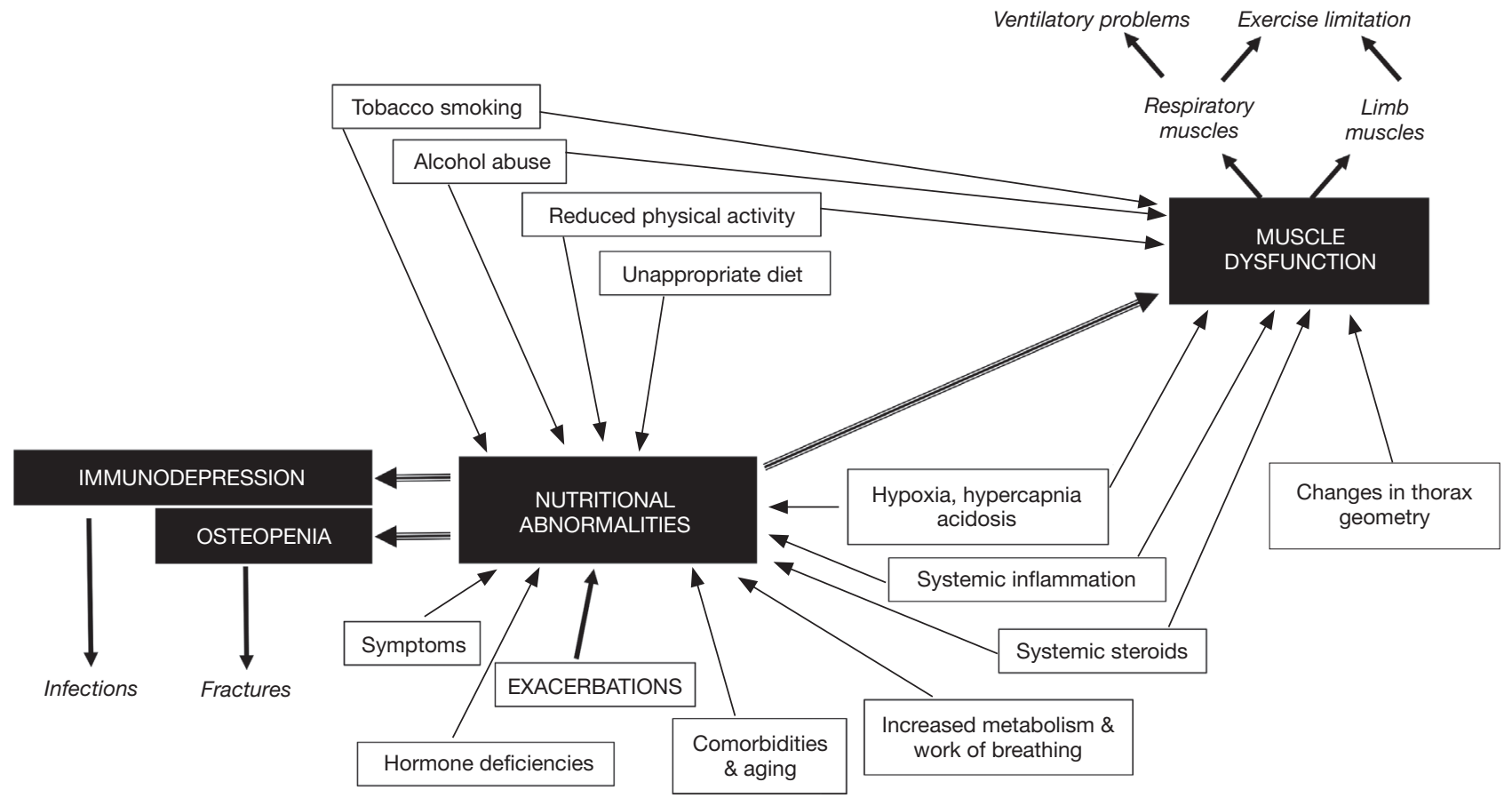

Figure 1 Different factors that contribute to nutritional abnormalities and/or muscle dysfunction. Note the relevant role of exacerbations, when many of the factors involved in nutritional abnormalities increase their influence. The most relevant clinical consequences of nutritional abnormalities and muscle dysfunction are also shown.

\section{Inappropriate diet, anorexia and malabsorption}

The caloric intake of patients with chronic respiratory disorders is often inadequate, not matching their energy requirements. More specifically, it has been shown that they consume less carbohydrates, proteins, different vitamins and omega 3 fatty acids than healthy subjects $(40,41)$. In addition, those patients with $\mathrm{CF}$ also add malabsorption due to the associated impairment in exocrine pancreatic function (42). A relevant symptom that frequently appears in chronic respiratory diseases is anorexia (43-45), defined as a reduction or loss of appetite. This symptom can be related to the lung disease itself but also to the treatment and/or the accompanying emotional distress, and can worsen nutritional abnormalities. The biological mechanisms of anorexia are not fully understood but recent evidence suggests a major role for neurohormonal and inflammatory cytokine systems (46-48). Closely related to the reduction in caloric intake is the coexisting imbalance with energy expenditure. A hypermetabolic status occurs in many patients with chronic respiratory conditions as a result of different metabolic disarrangements and increases in the work of breathing (49-52). All these elements result in a negative nutritional and energy balance that would also lead to a loss of muscle mass and muscle dysfunction.

\section{Systemic inflammation}

It is well known that many inflammatory mediators are capable of inducing anorexia and an increase in the degradation of intracellular proteins either through the direct activation of proteolytic pathways or development of oxidative stress $(53,54)$. A relative low level of systemic inflammation has been demonstrated in blood and other extrapulmonary tissues in different chronic respiratory diseases, such as COPD, IPF or bronchiectasis, even in periods of clinical stabilization (55-59). Although it is probable that the initial inflammatory process taking place in the lung becomes disseminated through systemic circulation reaching other organs ('spill over' theory), in non-CF bronchiectasis and IPF $(55,60)$, systemic inflammation can also be the result of the direct action of the same etiological factors involved in lung disease. This is probably the case in COPD $(26,61)$ and CF $(62)$. Certainly, both mechanisms can coexist in many cases, as it can reasonably be assumed for lung cancer (63). In either 
case, the resulting systemic inflammation seems to be a significant contributor to nutritional abnormalities and muscle dysfunction occurring in some chronic respiratory disorders (e.g., COPD or bronchiectasis) $(2,9,12)$, and may be a cofactor in others (e.g., IPF).

\section{Systemic oxidative stress}

Oxidative stress is directly linked with systemic inflammation. Reactive oxygen species (ROS) and nitric oxide (NO) are normally present in different tissues including skeletal muscles, playing different physiological roles. However, when there is an increase in oxygen or nitrogen reactants and/or the antioxidants are unable to counterbalance their effects, oxidative and/or nitrosative stress may occur. These phenomena lead to structural and functional abnormalities $(64,65)$. In this regard, free radical stress is believed to be involved in the pathogenesis of different chronic lung diseases, as well as in their systemic manifestations $(27,66,67)$.

\section{Hypoxemia, hypercapnia and acidosis}

Ventilation-perfusion mismatching present in chronic respiratory conditions frequently results in chronic hypoxia, with or without hypercapnia and acidosis. Moreover, respiratory muscle dysfunction can induce some degree of hypoventilation, also contributing to gas exchange abnormalities. Conversely, hypoxia can result in nutritional abnormalities, muscle dysfunction and exercise limitation $(68,69)$. This is probably the consequence of different phenomena such as systemic inflammation, which in turn deteriorates both tisular metabolism and the action of some peptides and hormones (i.e., leptin, ghrelin and AMP-activated protein kinase) involved in either appetite mechanisms or the maintenance of muscle, bone and fat masses. As a result, deleterious phenomena such as muscle autophagy and apoptosis, reduced mitochondrial synthesis (biogenesis), impaired proteostasis and regeneration, as well as metabolic limitations in the aerobic pathways develop within the muscle (70-73). Hypercapnia and acidosis in turn may also induce a decrease in energy stores, impaired muscle proteostasis and defective contractility (74-76).

\section{Hormonal deficiencies}

The effect of anabolic hormones can be altered in different chronic respiratory diseases. This is the case with COPD, where hypogonadism and low levels of androgens appear to be relatively prevalent, at least in those patients with loss of muscle mass (77). Some reports also indicate that COPD patients can show either a decrease in the levels of growth hormone $(\mathrm{GH})$ or the inefficiency of its anabolic axis, which also includes the GH releasing factor (GRF) and the insulin-like growth factor 1 (IGF-1) (12,78). Moreover, the prevalence of diabetes mellitus (DM) is increased in different chronic respiratory diseases. In COPD patients, for instance, it almost doubles (19\%) that observed in the general population (79). This has been explained by the presence of cigarette smoking, obesity, reduced physical activity, systemic inflammation, corticosteroid exposure and hypoxia (80). The prevalence of DM is even higher in adults with CF (close to 50\%), due in this case to pancreatic atrophy and some of the factors already mentioned for COPD (81). Conversely, patients with DM are more susceptible to pulmonary infections (including tuberculosis) (82), which can facilitate bronchiectasis. IPF also shows an increased prevalence of DM type II (10-33\%), which persist after exclusion of patients treated with systemic steroids $(83,84)$. Diabetes can lead to nutritional derangements, with loss of body and muscle weight, and muscle dysfunction. The mechanism for the latter probably involve insulin resistance, hyperglycemia, muscle fat infiltration and peripheral neuropathy (85).

Lung cancer, and particularly small cell lung cancer (SCLC), relatively frequently induces paraneoplastic syndromes, which are mainly caused by the production of cytokines by the neoplasm or as an immune response to cancer. The most common paraneoplastic expressions of lung cancer are fatigue and cachexia, as well as neurological, hematological and endocrine syndromes. Regarding the latter, lung tumors can synthesize and secrete peptides or hormones that cause a variety of endocrine syndromes. Some of them can be related with nutritional abnormalities or muscle dysfunction. This is the case of hypercalcemia (2-12\% of lung cancers), inappropriate antidiuretic hormone secretion (SIADH, 7-16\% in SCLC), ectopic Cushing's syndrome (2-5\% of SCLC, generally resulting from extrapituitary secretion of ACTH), and hypoglycemia (usually caused by the tumor production of IGF). All these disorders can induce muscle weakness and fatigue (86). Patients with lung cancer can also show low serum testosterone that is probably secondary to inhibition of follicle-stimulating hormone (FSH) (87). Other nonendocrinological paraneoplastic syndromes that can induce muscle dysfunction are the Lambert-Eaton myasthenic 
one (a presynaptic disorder of neuromuscular transmission) and polymyositis/dermatomyositis (an autoimmune-based systemic inflammatory myopathy), both leading to muscle weakness (86).

\section{Vitamin D deficiency}

A significant number of patients with chronic respiratory disorders also show decreased levels of both vitamin D and calcium (88-91). This circumstance, which can be partially related to a poor diet intake but also to a reduction in outside physical activities, may induce loss of bone and muscle mass, contributing to muscle dysfunction (89). Vitamin D insufficiency ranges between $40-77 \%$ in COPD patients (89), $40 \%$ in patients with bronchiectasis (88), and $60 \%$ in adults with CF (90) (reaching $90-95 \%$ in North American children with this disorder) (92). The prevalence of hypovitaminosis D in patients with lung cancer is close to $50 \%$ (91), reaching $90-95 \%$ in advanced disease; and remains very high even following supplementation therapy (93). Finally, vitamin D deficiency is also frequent in IPF, and a prevalence of $20-40 \%$ has been reported $(94,95)$. Interestingly, it has been suggested that vitamin D deficiency can contribute to a worse prognosis in both lung cancer and IPF $(96,97)$.

\section{Drugs}

Although other pharmacological treatments can have a negative impact on nutritional status, muscle structure and/ or function, systemic corticosteroids should be specially highlighted (10). These drugs can induce both chronic and acute myopathies (98). The former, characterized by weakness of proximal muscles, can appear even following low doses if they have been taken for a long period (99). By contrast, acute myopathy does not target specific muscle groups, appearing a few days after drug administration. In addition, systemic steroids can reduce synthesis of structural proteins and enhance protein degradation $(100,101)$.

\section{Comorbidities and aging}

Other chronic disorders are commonly associated to chronic respiratory diseases. In many cases this is simply because they share some of the etiological factors. Chronic heart failure, DM and cancer are among the most frequent comorbid conditions observed in respiratory medicine. By themselves they can also contribute to nutritional deficiencies and muscle dysfunction $(7,9,12,102,103)$. Moreover, aging alone can also induce loss of body weight, sarcopenia (loss of muscle mass associated with senescence), and muscle dysfunction (104). Therefore, special attention should be paid to elderly and comorbid patients.

\section{Chronic respiratory disorders}

Although a very detailed description of nutritional abnormalities and skeletal muscle dysfunction in all chronic respiratory diseases goes beyond the purposes and extension of the present review, it focuses on those entities that are especially targeted by these alterations.

\section{COPD}

Nutritional abnormalities frequently associate with COPD both by excess or fault. On the one hand, nutritional deficiencies seem to range between $15 \%$ and $50 \%$ $(105,106)$ in COPD patients from North America and Northern-Central Europe, being lower (3\% to 20\%) in the Mediterranean area $(107,108)$. This wide spectrum of data has been explained by differences in lifestyle but also in patients' selection and diagnosis criteria for malnutrition (techniques, variables and thresholds) (104). It is worth noting that nutritional deficiencies have been specifically associated with the emphysematous phenotype (pink puffer) of COPD as well as with alpha-1 antitrypsin deficiency, and are closely linked to muscle dysfunction (10). However, most of the recent COPD classifications undervalue the significance of nutritional abnormalities $(1,109)$, a circumstance that can be the explained by the absence of a well-defined treatment. In fact, only the BODE index and its derivates include body mass index (BMI) among variables used to determine the severity and prognosis of the disease (110). In agreement with these nutritional data, muscle dysfunction is also very frequent in COPD patients. This is the case for both limb (prevalence 20-30\%) and respiratory muscles (prevalence 20-45\%) (111-114). While nutritional abnormalities and deconditioning play a key role in the impairment showed by the former group, respiratory muscle dysfunction is mainly the result of geometrical changes occurring in the thorax as a direct result of the lung disease $(10,11)$.

In the particular case of patients with alpha- 1 antitrypsin deficiency, not only nutritional status, but also muscle mass and strength, and exercise capacity become impaired as well $(115,116)$.

However, a significant percentage of COPD patients 
exhibit obesity (defined by a BMI $>30 \mathrm{~kg} / \mathrm{m}^{2}, 20-30 \%$ of individuals) or overweight (BMI $25.0-29.9 \mathrm{~kg} / \mathrm{m}^{2}$, reaching around $40 \%$ in some of the studies) (117). Obesity can also be diagnosed by considering body composition [thresholds for fat mass index (FMI) are $\geq 6.6 \mathrm{~kg} / \mathrm{m}^{2}$ in men and $\geq 9.5 \mathrm{~kg} / \mathrm{m}^{2}$ in women, and for the percentage of body fat $\geq 25 \%$ for men and $\geq 35 \%$ for women] (118). The causes of obesity and overweight in COPD are similar but probably more pronounced than those causing these nutritional abnormalities in Western populations, and would include an inappropriate diet and low level of physical activity (117), as well as hormonal changes and some treatments that are also present in these patients.

It is worth noting that obesity does not necessarily involve maintenance of muscle mass, since the latter is often replaced by fat, mostly in female patients. Sarcopenic obesity is the term used for the association of obesity and muscle wasting. Although the loss of muscle mass can lead to all the negative functional consequences discussed above $(117,119)$, mild to moderate obesity has also been associated with lower mortality in COPD patients $(120,121)$. This has been attributed to the presence of energetic storages linked to obesity, which under acute circumstances would partially counterbalance the increased catabolism characteristic of severe or critical conditions. However, it must be taken into account that obesity also leads to cardiovascular and metabolic comorbidities and potentially to hypoventilation syndromes (119). Although there is a lack of consensus for clinical management of obesity in COPD patients, it seems logical to recommend a moderate weight reduction along with prevention of metabolic and cardiovascular complications.

\section{Non-CF bronchiectasis}

Bronchiectasis, defined as the abnormal and irreversible dilation of the bronchi, are frequently observed even in general population, especially since the wide use of the high-resolution computed tomography (122). Although bronchiectasis can be the result of different processes, they are currently classified in those linked to $\mathrm{CF}$ and those that are independent of such a genetic alteration (non-CF), being the latter much more prevalent (123-125). Moreover, the above-mentioned advances in image techniques have allowed for the identification of a variable number of COPD patients who also have bronchiectasis to a greater or lesser extent (1). Although the most common clinical presentation of non-CF bronchiectasis is the presence of daily cough with abundant sputum and repeated infections $(123,124)$, nutritional abnormalities are also frequent (2). Since many of the deleterious factors present in COPD are also present in non-CF bronchiectasis (local and systemic inflammation, exacerbations, ventilatory limitation, deconditioning, etc.) $(126,127)$, it could be speculated that muscle dysfunction would also be frequent in this case. However, the actual prevalence of this disorder in nonCF bronchiectasis remains unclear. Respiratory muscle dysfunction has only been occasionally described in this lung disease $(2,126,128,129)$ and, so far little attention has been given to the eventual presence of limb muscle malfunctioning. In fact, only isolated reports suggest that this latter abnormality is common in non-CF bronchiectasis $(130,131)$ and exercise tolerance can also be reduced (126).

\section{CF}

Nutritional abnormalities and peripheral muscle weakness are prevalent in adult and children with CF, being an independent predictor of mortality (132). Moreover, wasting associates with an impairment in muscle mass $(5,133)$, and a mean decrease of $25-35 \%$ in quadriceps strength $(5,133,134)$. This suggests that nutritional abnormalities also play a key role in this case (135), although other factors such as deconditioning, systemic inflammation or drugs may also participate $(5,136-138)$. Regarding respiratory muscles, their function can either be impaired, as is the case in the diaphragm, or preserved, as it appears to be the case in expiratory muscles. Both phenomena may be explained by the increase in loads undergone by the respiratory system, which would mainly affect the length and capacity to generate force in the former muscles but would generate a training effect in the latter $(133,135)$.

\section{IPF}

This is a fibrosing interstitial pneumonia of unknown etiology (139). Interestingly, it is worth noting that some COPD patients also associate fibrosis (1), and probably may constitute a specific phenotype of these disorders. In fact, close to $30 \%$ of IPF patients show some degree of concomitant emphysema $(140,141)$, which as previously mentioned frequently associates nutritional abnormalities and muscle dysfunction. Although many other comorbid conditions (cardiovascular, hormonal and digestive, among others) have been reported in IPF, the prevalence of nutritional abnormalities and skeletal muscle 
dysfunction have received poor attention. The prevalence of nutritional abnormalities in hypoxemic IPF patients has been estimated at around 30\% (142), Moreover, in a series of IPF candidates for lung transplantation, as much as $56 \%$ showed severe lean body mass depletion (143). However, body weight can occasionally be maintained due to a relative abundant fat mass (144). Interestingly, the nutritional status is a prognosis factor in IPF (3). Moreover, the weak relationship between exercise capacity and lung function observed in this disorder suggests the presence of additional factors. Some reports also suggest an impairment in peripheral and respiratory muscle function in IPF patients (145-147), leading to limitations in daily physical activities with a relevant impact on patients' life $(145,147)$. Moreover, this impairment seems to be partially reversible with training $(145,146,148)$, suggesting that in addition to the above mentioned nutritional abnormalities, there is a role for deconditioning and other factors such as treatment with systemic steroids (145).

\section{Lung cancer}

The development of cachexia is a common manifestation in advanced cancer, and is inversely related with time to survival (4). It constitutes a complex syndrome, which also includes anorexia. However, nutritional abnormalities may occur much earlier in lung cancer (149), predating clinically evident cachexia (150). In fact, people with lung cancer who are candidates for surgical lung resection (i.e., those with a still localized neoplasm) perceive physical weakness as the most important and undesirable symptom (151). Nutritional abnormalities associated to lung cancer are related to anorexia but also to a hypermetabolic status, where the host and the tumor compete for nutrients. These nutrients can come from diet but also from the patient's own metabolism. This is especially dramatic in the case of proteins since their synthesis is decreased and breakdown is increased in cancer. Since skeletal muscles account for around half of the entire body protein content, it is easy to anticipate that muscle mass would be affected, leading to muscle dysfunction (4). This muscle mass reduction and the subsequent muscle weakness appears to be the most relevant clinical event induced by cancer cachexia (152), since they result in significant impairment in quality of life, exercise capacity, physical functions and mortality (153-155). As for different muscle groups, patients with thoracic cancers have been shown to have lower quadriceps strength than healthy controls (156). Regarding etiology for the preceding abnormalities, most of the factors already mentioned for other respiratory conditions are also present in lung cancer, which in addition is frequently associated to COPD. These factors include, not only nutritional abnormalities but also a low level of physical activity and muscle deconditioning, tobacco exposure, systemic inflammation (most likely, cytokines such as TNF-alpha or IL-1) and oxidative stress, aging, comorbidities and cancer treatments $(4,157,158)$. Respiratory muscle function in turn will also be influenced by changes undergone by thorax mechanics as a result of the neoplasm and underlying disorders.

Aging in particular is a factor that can contribute in a relevant way to sarcopenia and muscle dysfunction in patients with lung cancer. In fact, as many as half of the newly diagnosed neoplastic patients are older than 70 years in developed countries (159), and of them, $50 \%$ show nutritional abnormalities (160-163), with the vast majority (around 70\%) also exhibiting altered physical capacity (161).

Lung cancer treatment, which can include surgery, chemotherapy, radiotherapy and immunotherapy, is an additional factor that can contribute to nutritional and skeletal muscle abnormalities. Radiotherapy for instance can induce esophagitis-dysphagia and anorexia, whereas chemotherapy can cause nausea and vomiting, both affecting the ability to achieve an adequate dietary intake $(164,165)$. As to surgical resection it involves the loss of lung function and respiratory symptoms, which in turn can lead to a reduction in physical activities as well as to cardiovascular and skeletal muscle deconditioning. Finally, all these treatment regimens can increase the anxietydepression symptoms linked to the diagnosis of lung cancer, also leading to a reduction in physical activity and social life. Interestingly, a systematic review indicates that dietary counseling or nutritional supplements can improve protein intake in patients undergoing chemotherapy (166). The same review shows that these measures are able to maintain the nutritional status in lung cancer patients receiving radiotherapy (166).

\section{Exacerbations}

These periods, characterized by the impairment of symptoms, can be present in different chronic respiratory conditions. Although they are more characteristic of COPD, CF and non-CF bronchiectasis, they can also contribute to the deterioration of patient performance in IPF and lung cancer. Exacerbations bring together many of the different factors that can contribute to nutritional 
abnormalities and skeletal muscle dysfunction (9).

\section{COPD}

Exacerbations increase the level of local and systemic inflammation markers (see previous sections) $(12,167)$ as well as those of leptin. Moreover, anorexia, fever, reduced physical activity, a negative energy balance, increases in the work of breathing and use of systemic steroids are often added to this adverse metabolic picture, which negatively impacts on nutritional status and muscle function $(9,168-170)$. It should be noted that muscle wasting and dysfunction can develop early in acute episodes, lasting for a relatively long time (9). In fact, many authors consider that exacerbations are one of the factors that contribute the most to these abnormalities $(9,12)$. In close agreement with this idea, muscle dysfunction has been shown to reach a prevalence of $80-90 \%$ in patients with multiple hospital admissions due to exacerbations (114). Conversely, those patients with muscle dysfunction show an increased risk of hospital admission due to these acute events $(114,171)$.

\section{Non-CF bronchiectasis}

Acute exacerbations are also frequent in this disorder, being accompanied by many of the factors that are also present in COPD (dramatic decrease in physical activity, increase in lung and systemic inflammation, metabolic derangement between energetic requirements and offers, drugs with potential negative effect on muscle tissue, etc.) (172).

\section{CF}

Weight loss is so important in CF exacerbations that it has been included in its definition (173), having also specific therapeutic measures that have been incorporated in the guidelines (173). As in other chronic respiratory disorders acute episodes are characterized by a marked catabolic state combined with reduced appetite and physical activity, and inflammatory events. Moreover, insulin-requirements can be dramatically increased during CF exacerbations (173). As a result of these factors, quadriceps maximal strength decreases acutely during the episode $(174,175)$, although it generally recovers in the follow-up (174).

\section{IPF}

The natural history of this disorder is highly variable, but some patients show acute deteriorations among periods of relative stability (176). Although little is known about the pathophysiology of these acute events, it has been shown that systemic inflammation levels become increased (60). As in the other disorders included in the present review, this factor would be added to a greater reduction in physical activity, impairment in gas exchange, and a worse nutritional balance.

\section{Diagnosis}

\section{Nutritional abnormalities}

The actual prevalence of nutritional deficiency in chronic respiratory conditions is relatively high, although precise rates depend mainly on the criteria used for the diagnosis. These are commonly based on anthropometric variables [body weight, percentage of ideal body weight (\%IBW), or BMI, ratio between weight in $\mathrm{kg}$ and height in square meters] or, even better, data from the analysis of body composition [such as fat free mass index (FFMI)] (Figure 2). The simplest but less specific is to obtain direct or derived anthropometric variables. Values under $80 \%$ in \%IBW or $18-18.5 \mathrm{~kg} / \mathrm{m}^{2}$ in BMI are commonly considered as the diagnostic thresholds for impaired nutritional status $(177,178)$. BMI can also be used to stratify such a deficit in mild-moderate $\left(16-18 \mathrm{~kg} / \mathrm{m}^{2}\right)$, severe $\left(15-15.9 \mathrm{~kg} / \mathrm{m}^{2}\right)$ and very severe (below $15 \mathrm{~kg} / \mathrm{m}^{2}$ ) (178). Other traditional anthropometric determinations are triceps skinfold or thigh circumference, but they have been progressively abandoned in the clinical setting. However, anthropometric measurements can be poorly sensitive to mild-to-moderate nutritional abnormalities. A more appropriate approach is to determine body composition using bioelectrical impedance or dual-energy X-ray absorptiometry (DEXA) $(7,179)$. Both methods provide an accurate approximation of fat free mass, which in the case of the latter technique can even offer compartmentalization in different body parts such as trunk, upper or lower limbs. FFMI is the body composition variable most widely used to assess nutritional status. Values lower than $16-18 \mathrm{~kg} / \mathrm{m}^{2}$ in men, and $14.5-15 \mathrm{~kg} / \mathrm{m}^{2}$ in women $(105,180)$ are indicative of muscle mass loss. It should be noted that diagnosis of nutritional deficiencies can be especially difficult in female patients, since they can show loss of muscle mass even though body weight remains relatively stable, showing significant discrepancies between BMI and FFMI (105). Other methods that can also be used to assess nutritional status are imaging techniques (computed tomography, magnetic resonance 


\begin{tabular}{|c|c|}
\hline & Muscle function assessment \\
\hline $\begin{array}{l}\text { Anthropometry } \\
\text { Weight } \\
\text { \% Ideal Body Weight (IBW) } \\
\text { Body Mass Index (BMI) } \\
\text { Triceps skinfold } \\
\text { Thigh circumference } \\
\text { Determination of Body Composition } \\
\text { Bioelectrical Impedance (FFMI) } \\
\text { DEXA } \\
\text { Deuterium dilution } \\
\text { Ultrasounds } \\
\text { Air displacement plethysmography } \\
\text { CT, MRI, others } \\
\text { Blood analysis (proteins, albumin, cholesterol, etc.) } \\
\text { Cachexia Scores (CASCO, MCASCO) }\end{array}$ & $\begin{array}{l}\text { Clinical Semiology } \\
\text { High respiratory frequency } \\
\text { Dyspnea in supine } \\
\text { Use of accessory muscles } \\
\text { Thorax-Abdomen incoordination } \\
\text { Upper-Lower thorax incoordination } \\
\text { Difficulties for coughing } \\
\text { Limb symptoms } \\
\text { Imaging Techniques } \\
\text { Chest X-ray } \\
\text { Ultrasounds } \\
\text { CT, MRI, others } \\
\text { Conventional lung function } \\
\text { MVV, MSV } \\
\text { Forced spirometry } \\
\text { Spirometric impairment in supine } \\
\text { Plethysmography (static lung volumes) } \\
\text { Hypoxemia with hypercapnia } \\
\text { Nocturnal hypoxemia } \\
\text { Specific tests for muscles } \\
\text { Maximal respiratory pressures (strength) } \\
\text { Limb dynamometry (strength) } \\
\text { Induced contraction, twitch (strength) } \\
\text { Submaximal tests (endurance) }\end{array}$ \\
\hline
\end{tabular}

Figure 2 Techniques and the most relevant variables used for nutritional and muscle function assessments. Note that both abnormalities are closely related since the presence of malnutrition often contributes to the occurrence of muscle dysfunction. FFMI, fat-free mass index; DEXA, dual-energy X-ray absorptiometry; CT, computed tomography; MRI, magnetic resonance imaging; CASCO, CAchexia SCOre; MCASCO, mini-CASCO score; MVV, maximum voluntary ventilation; MSV, maximum sustainable ventilation.

and ultrasounds), air displacement plethysmography (ADP), deuterium dilution, and isotopic techniques $(7,11,179,180)$. Blood determinations of serum total proteins, albumin fraction, cholesterol and prothrombin time can also be useful to complete the assessment of nutritional status (7). An interesting 'CAchexia SCOre' (CASCO) has been recently validated and can be useful in chronic respiratory conditions. It includes several domains (body weight loss and composition, inflammation/metabolic disturbances, immunosuppression, physical performance, anorexia and quality of life), and classifies patients from 'non-cachectic' to 'with severe cachexia' (181). Since this score involves multiple variables, a simplified version (miniCASCO or MCASCO), which only involves body weight-lean mass, blood analysis and a short questionnaire, has also been recently developed for clinical purposes (182).

\section{Muscle dysfunction}

Although closely related, nutritional deficiencies and muscle dysfunction are not always associated. Thus, specific methods should be used to directly assess muscle function $(12,13)$ (Figure 2).

Functional evaluation of respiratory muscles can be addressed with different approaches from clinical semiology to instrumentalized techniques. On the one hand, muscle dysfunction can be suggested by the presence of different symptoms and signs such as a very high respiratory rate with small tidal volume, a relevant worsening of dyspnea when lying in supine, the use of accessory muscles for ventilation, thoraco-abdominal or upper-lower chest incoordination, and difficulties in effective coughing (11). Imaging techniques, such as conventional chest X-ray and ultrasounds, can also be useful to suggest the presence of respiratory muscle dysfunction $(183,184)$. From a functional point of view, a marked impairment in forced vital capacity (FVC), a $25 \%$ reduction in this parameter when changing from sitting to the supine position, as well as a decrease in static lung volumes [such as total lung capacity (TLC) or functional residual capacity (FRC)], and hypoxemia 
with hypercapnia (especially at night) can be the result of respiratory muscle dysfunction $(11,185)$. More specific are those techniques that allow determination of maximum respiratory pressures as an expression of muscle strength. Their measurement at the mouth, using dynamic or static maneuvers (i.e., with or without concomitant airflow, respectively), is the most commonly used procedure in clinics. While maximum inspiratory pressure (MIP) is usually determined from residual volume (RV), maximum expiratory pressure (MEP) is commonly measured from TLC (186). However, both can also be determined from FRC. MIP and MEP values can be expressed in absolute and relative terms since validated references exist for both variables $(186,187)$. Values below $80 \mathrm{cmH}_{2} \mathrm{O}$ or $65 \%$ of the reference are considered as indicative of respiratory muscle dysfunction $(13,188)$. Alternatively, maximum pressures can be determined on the nostrils during a maneuver of forced inhalation [sniff nasal inspiratory pressure (SNIP)] $(189,190)$, and values lower than -60 or $-70 \mathrm{cmH}_{2} \mathrm{O}$ are accepted as suggestive of inspiratory muscle dysfunction (13). Validated reference values are also available in this case $(191,192)$. Since all the above-mentioned measurements are valid only in the presence of normal upper airways, it may be necessary to perform a more invasive technique in some patients. In this case, maximal esophageal pressure (Pesmax, which closely reflects pleural pressure) (193) and/or transdiaphragmatic pressure (Pdimax) should be determined (194,195). A Pesmax lower than -70 or $-80 \mathrm{cmH}_{2} \mathrm{O}$ or a Pdimax above 50 (women) or 75 (men) $\mathrm{cmH}_{2} \mathrm{O}$ are highly suggestive of inspiratory muscle dysfunction $(11,13,194)$. A common limitation to all these procedures is the need for patient collaboration. When this is not possible, maximum muscle contraction can be induced by supramaximal electrical or magnetic stimulation ('twitch') $(9,196,197)$. The latter is better tolerated since the former is uncomfortable and can even be painful $(11,197)$. Approximations to reference values with twitch stimulation of the diaphragm have also been published $(13,198,199)$. Values lower than $50-60 \mathrm{cmH}_{2} \mathrm{O}$ in men and $35-40 \mathrm{cmH}_{2} \mathrm{O}$ in women are considered as indicative of diaphragm dysfunction, and below $15 \mathrm{cmH}_{2} \mathrm{O}$ would evidence a serious muscle malfunction $(11,13)$. Less extended is determination of those variables that reflect muscle endurance. The simplest are maximum voluntary ventilation (MVV) and maximum sustainable ventilation (MSV), although they are both very unspecific (11). A good alternative is determination of the time elicited by the patient sustaining a percentage of the maximum respiratory pressure until task failure (Tlim) (200-203).

Functional assessment of peripheral muscles in turn, can also be approximated by clinical semiology. In this case, the presence of lower limb symptoms during even mildto-moderate exercise or an evident loss of muscle mass are both suggestive of limb muscle dysfunction $(204,205)$. Those techniques used to assess body composition, which have been detailed previously, can also help in the suspicion of an impairment in muscle function. However, as occurs for respiratory muscles, there are specific tests to assess limb muscle function. The strength can be determined by dynamometry, generally using a maximal isometric maneuver. Handgrip is most often used for assessing upper limb strength, whereas quadriceps isometric contraction is usually employed for lower limbs (11). Quadriceps strength can also be determined by measuring the peak torque at fixed joint angle speed $(206,207)$, although this technique requires more experience. Reference values are available for both handgrip and quadriceps dynamometers (208-212). In the case of handgrip, values below $80-85 \%$ pred. have been proposed as suggestive of upper limb muscle dysfunction, whereas the threshold for quadriceps muscle is more controversial $(213,214)$. As in the case of respiratory muscles, electrical or magnetic stimulation can be used in subjects unable to participate in the maneuver $(215,216)$, and reference values are also available $(11,217)$. Limb muscle endurance can also be approximated using procedures and variables very similar to those used with respiratory muscles (e.g., Tlim) (218-221).

\section{Therapy}

As so many factors can contribute to nutritional abnormalities and muscle dysfunction in chronic respiratory disorders, the therapeutic approach should be multidimensional (Table 1). Unhealthy lifestyle must be modified and patients should increase their physical activity, improve the quality of their diet, and abstain from tobacco smoking and alcohol. It is also important to prevent and appropriately treat exacerbations and avoid, or at least, reduce treatments with drugs that are deleterious to nutritional status and muscle function.

When these measures become insufficient, dietary supplements or anabolic drugs can be used. Similarly, training programs would contribute to reconditioning not only of the skeletal muscles but of the cardiovascular system. 
Table 1 Therapeutic measures for nutritional abnormalities and muscle dysfunction. Most of them act on both problems

\author{
Healthy lifestyle \\ Avoid smoking and alcohol \\ Maintain good level of physical activity \\ Balance diet \\ Ensure healthy aging \\ Diet supplements (if healthier lifestyle is not enough) \\ Optimize the control of the underlying respiratory disease and its \\ comorbidities \\ Bronchodilators, inhaled steroids or oxygen if necessary \\ Avoid Exacerbations and optimize their management: vaccines, \\ antibiotics, enriched diet (+ supplements?) \& early mobilization. \\ Training? \\ Avoid systemic steroids if possible \\ Treat and monitorize comorbidities \\ Training (potentiates nutritional actions) \\ Exercise training, interval training, resistance training \\ Respiratory muscle training (if indicated) \\ Stimulated training (patients unable to collaborate) \\ Anabolic drugs (only selected cases) \\ Androgens, SARM \\ $\mathrm{GH}, \mathrm{GH}$ secretagogues, growth factors \\ Other drugs \\ Antioxidants and anti-inflammatory (no clear effects) \\ Appetite enhancers (?) \\ Potentiators of muscle contraction (calcium sensitizers)
}

Rest (if there is a fatigue component): mechanical ventilation

SARM, selective androgen receptor modulators; GH, growth hormone.

\section{Avoid tobacco smoking}

This simple measure is able to improve nutritional status and muscle mass and function through different positive effects (222). On the one hand, it will eliminate the anorectic effect of tobacco, improving diet quality (223). On the other, systemic inflammation and oxidative stress, as well as protein synthesis/breakdown imbalance will be reduced, with improvements in body weight, as well as in muscle mass and function (224-227).

\section{Dietary recommendations}

To cope with nutritional abnormalities, it is important to emphasize the necessity of increasing the intake of proteins and polyunsaturated fatty acid-rich foods, as well as vitamins (such as A, B6, B9, B12, C, D, and E) (228-230). It also appears to be positive to increase the consumption of fibers, as this can delay the progression of some chronic respiratory diseases, perhaps through its effects on bowel microbiome $(231,232)$.

\section{Nutritional supplements}

These can be used as an adjunct to an appropriate diet in order to achieve better results. Supplements should essentially provide an additional amount of calories, but also proteins, amino acids (especially those of branched chain), vitamins and minerals $(123,168,233)$. Liquid supplements with high-caloric content are especially helpful in restoring body weight and skeletal muscle mass in patients with some chronic respiratory disorders (234). However, some recent reviews have not demonstrated clear benefits in others, when there is an already well-balanced diet (235). Regarding protein and amino acid content, the source of the supplement is also important. Those derived from milk or whey appear to be better absorbed and utilized than those obtained from soybean $(168,236)$. In the case of CF, pancreatic enzyme replacement is mandatory.

\section{Appetite stimulants}

Positive results have not been demonstrated with the administration of these drugs (such as megestrol, donabiol or pentoxifylline) in underweight chronic respiratory patients (237).

\section{Appropriate level of physical activity and training}

Sedentarism, psychological symptoms, skeletal muscle dysfunction and, in some cases, ventilatory limitation, lead to reduced physical activities, which conversely will aggravate these same causes. This vicious circle should be broken by recommending an increase in outdoor physical activities (11); a simple measure that can reduce hospital admissions and improve prognosis and quality of life in COPD (238-240). Although it also appears to be able to ameliorate some of these outcomes in other chronic respiratory diseases, more studies are needed $(241,242)$. 
When physical activity is insufficient for obtaining positive results, training programs should be recommended (243). These are able to improve cardiovascular and muscle function, increasing exercise capacity and reducing anxiety and depression symptoms (11,244-250). In addition, many of the structural and metabolic abnormalities shown by skeletal muscles will erode or even disappear with training $(251,252)$. General training has different modalities including endurance exercise training, which is crucial for obtaining an improvement in muscle function and physical capacity (11,253-255). Strength and resistance training in turn can also be helpful for specifically ameliorating these functional properties of skeletal muscles. Both the intensity of loads and the pattern of repetitions will determine improvements in strength, endurance or both $(201,254)$. An important point is to reach an acceptable nutritional status before starting an intense training program (255). In fact, dietary measures and training potentiate each other, obtaining better results with an appropriate combination $(6,52,234)$. It is also relevant to initiate training at a moderate level, since high intensity exercise can cause muscle oxidative stress in untrained patients (256). A negative effect that can be easily avoided with progressive increases in the effort requirements until achieving an acceptable level of cardiovascular and muscle conditioning (257). In patients with a very limited exercise capacity, who cannot follow volitional training modalities, it may be necessary to use electric or magnetic stimulation of skeletal muscles (258-261). A very interesting and still controversial point is whether it is beneficial, or not, to train patients during or immediately following exacerbations. Although there is some evidence suggesting that this procedure can prevent loss of muscle mass and function during these acute episodes (262), further studies are needed and probably, the therapeutic approach should be individualized taking into account the underlying disease and patient's condition (11,263-265).

\section{Anabolics}

These drugs are only necessary in highly selected cases, and most are hormone derivates or releasers, notably those related to androgens or the GH. Some of the former, such as testosterone or nandrolone, are able to enhance the balance between protein synthesis and breakdown, increasing muscle mass $(12,78)$. However, they can also produce undesirable side effects, which can nonetheless be reduced with the use of selective androgen receptor modulators (SARM) (266). As for GH, it also has a powerful anabolic effect, being able to increase body weight in chronic respiratory patients with malnutrition, but unfortunately not demonstrating systematically a clear improvement in muscle function (267). The same appears to be the case for GH secretagogues (drugs that promote synthesis or release of GH) such as ghrelin, tesamorelin and anamorelin. Nevertheless, there are some reports showing functional improvements associated with the gain of body and muscle weight with these drugs $(268,269)$.

\section{Control of the underlying lung disorder}

Naturally, a good control of the chronic respiratory disease contributes to maintaining nutritional status and muscle function $(11,104)$. This is especially important regarding prevention and treatment of exacerbations, when many of the factors leading to nutritional abnormalities and muscle dysfunction become even more accentuated. The therapeutic measures mainly include the use of bronchodilators, vaccines and antibiotics in COPD and bronchiectasis, and the latter drugs and anti-fibrotic therapies in IPF. Although systemic steroids can be necessary, their dose and the duration of the treatment should be carefully considered. An appropriate and more caloric diet (270), as well as early mobilization of the patient are also very important. Moreover, more recently it has been suggested that initiating training during or immediately post-exacerbation can partially counterbalance the deleterious effects of these acute episodes $(271,272)$.

\section{Drugs with anti-inflammatory and antioxidant effect}

Different substances have been tested so far in order to neutralize local and systemic inflammation and oxidative stress. This is the case of antioxidant substances and antibodies against inflammatory cytokines, their receptors, or some transcription factors. However, the evidence of positive effects is scarce and some of these therapies have also shown important side effects (273-277).

\section{Conclusions}

Nutritional abnormalities and muscle dysfunction are frequently found in patients with chronic respiratory disorders such as COPD, non-CF bronchiectasis, CF, IPF and lung cancer. These defects can appear together or separately, although they are closely interrelated and share 
many different etiological factors. Diagnosis of nutritional abnormalities include anthropometry and determination of different body components (mainly obtained through bioelectrical impedanciometry), whereas that of muscle dysfunction involves determination of muscle strength and endurance. The treatment of underweight patients includes the improvement of lifestyle habits, dietary supplements and, in some particular cases, the use of anabolic drugs. These measures should be accompanied by training, especially in those patients with muscle dysfunction.

\section{Acknowledgements}

Thanks To Jonathan McFarland for his editing help with the present manuscript.

Funding: Partially funded by Grants SAF2014-54371 (Fondos FEDER) and CIBERES from the Spanish Government, 2014SGR424 from the Catalan Government, and SEPAR 2014 y 2015.

\section{Footnote}

Conflicts of Interest: The authors have no conflicts of interest to declare.

\section{References}

1. Vogelmeier CF, Criner GJ, Martínez FJ, et al. Global Strategy for the Diagnosis, Management, and Prevention of Chronic Obstructive Lung Disease 2017 Report: GOLD Executive Summary. Arch Bronconeumol 2017;53:128-49.

2. Olveira G, Olveira C, Gaspar I, et al. Fat-free mass depletion and inflammation in patients with bronchiectasis. J Acad Nutr Diet 2012;112:1999-2006.

3. Alakhras M, Decker PA, Nadrous HF, et al. Body mass index and mortality in patients with idiopathic pulmonary fibrosis. Chest 2007;131:1448-53.

4. Gea J, Barreiro E, Orozco-Levi M. Skeletal muscle adaptations to disease states. Chapter 11. In: Bottinelli R, Reggiani C. editors. Skeletal Muscle Plasticity in Health and Disease: From Genes to Whole Muscle. Dordrecht: Springer, 2006:315-60.

5. Troosters T, Langer D, Vrijsen B, et al. Skeletal muscle weakness, exercise tolerance and physical activity in adults with cystic fibrosis. Eur Respir J 2009;33:99-106.

6. Schols AM, Slangen J, Volovics L, et al. Weight loss is a reversible factor in the prognosis of chronic obstructive pulmonary disease. Am J Respir Crit Care Med 1998;157:1791-7.

7. Gea J, Martínez-Llorens J, Barreiro E, et al. Nutritional abnormalities in chronic obstructive pulmonary disease. Med Clin (Barc) 2014;143:78-84.

8. Matel JL, Milla CE. Nutrition in cystic fibrosis. Semin Respir Crit Care Med 2009;30:579-86.

9. Gea J, Agustí A, Roca J. Pathophysiology of muscle dysfunction in COPD. J Appl Physiol 2013;114:1222-34.

10. Gea J, Pascual S, Casadevall C, et al. Muscle dysfunction in chronic obstructive pulmonary disease: update on causes and biological findings. J Thorac Dis 2015;7:E418-38.

11. Gea J, Casadevall C, Pascual S, et al. Clinical management of chronic obstructive pulmonary disease patients with muscle dysfunction. J Thorac Dis 2016;8:3379-400.

12. Maltais F, Decramer M, Casaburi R, et al. An official American Thoracic Society/European Respiratory Society statement: update on limb muscle dysfunction in chronic obstructive pulmonary disease. Am J Respir Crit Care Med 2014;189:e15-62.

13. Barreiro E, Bustamante V, Cejudo P, et al. Guidelines for the evaluation and treatment of muscle dysfunction in patients with chronic obstructive pulmonary disease. Arch Bronconeumol 2015;51:384-95.

14. Barreiro E. Skeletal Muscle Dysfunction in COPD: Novelties in the last decade. Arch Bronconeumol 2017;53:43-4.

15. Gosselink R, Troosters T, Decramer M. Peripheral muscle weakness contributes to exercise limitation in COPD. Am J Respir Crit Care Med 1996;153:976-80.

16. Swallow EB, Reyes D, Hopkinson NS, et al. Quadriceps strength predicts mortality in patients with moderate to severe chronic obstructive pulmonary disease. Thorax 2007;62:115-20.

17. Decramer M, Gosselink R, Troosters T, et al. Muscle weakness is related to utilization of health care resources in COPD patients. Eur Respir J 1997;10:417-23.

18. Shrikrishna D, Patel M, Tanner RJ, et al. Quadriceps wasting and physical inactivity in patients with COPD. Eur Respir J 2012;40:1115-22.

19. Ferrari K, Goti P, Misuri G, et al. Chronic exertional dyspnea and respiratory muscle function in patients with chronic obstructive pulmonary disease. Lung 1997;175:311-9.

20. Killian KJ, Leblanc P, Martin DH, et al. Exercise capacity and ventilatory, circulatory, and symptom limitation in patients with chronic airflow limitation. Am Rev Respir Dis 1992;146:935-40. 
21. Roche N, Zureik M, Soussan D, et al. Predictors of outcomes in COPD exacerbation cases presenting to the emergency department. Eur Respir J 2008;32:953-61.

22. Díaz MC, Ospina-Tascón GA, Salazar CB. Respiratory muscle dysfunction: a multicausal entity in the critically ill patient undergoing mechanical ventilation. Arch Bronconeumol 2014;50:73-7.

23. Ambrosino N. Weaning and respiratory muscle dysfunction: the egg-chicken dilemma. Chest 2005;128:481-3.

24. Petersen AM, Magkos F, Atherton P, et al. Smoking impairs muscle protein synthesis and increases the expression of myostatin and MAFbx in muscle. Am J Physiol Endocrinol Metab 2007;293:E843-8.

25. Wüst RC, Morse CI, de Haan A, et al. Skeletal muscle properties and fatigue resistance in relation to smoking history. Eur J Appl Physiol 2008;104:103-10.

26. Zhang J, Liu Y, Shi J, et al. Side-stream cigarette smoke induces dose-response in systemic inflammatory cytokine production and oxidative stress. Exp Biol Med (Maywood) 2002;227:823-9.

27. Barreiro E, Peinado VI, Galdiz JB, et al. Cigarette smokeinduced oxidative stress: A role in chronic obstructive pulmonary disease skeletal muscle dysfunction. Am J Respir Crit Care Med 2010;182:477-88.

28. Rom O, Kaisari S, Aizenbud D, et al. Sarcopenia and smoking: a possible cellular model of cigarette smoke effects on muscle protein breakdown. Ann N Y Acad Sci 2012;1259:47-53

29. Corwin EJ, Klein LC, Rickelman K. Predictors of fatigue in healthy young adults: moderating effects of cigarette smoking and gender. Biol Res Nurs 2002;3:222-33.

30. Morse CI, Wüst RC, Jones DA, et al. Muscle fatigue resistance during stimulated contractions is reduced in young male smokers. Acta Physiol (Oxf) 2007;191:123-9.

31. Grant BF, Hasin DS, Chou SP, et al. Nicotine dependence and psychiatric disorders in the United States: Results from the National Epidemiologic Survey on Alcohol and Related Conditions. Arch Gen Psychiatry 2004;61:1107-15.

32. Steiner JL, Lang CH. Dysregulation of skeletal muscle protein metabolism by alcohol. Am J Physiol Endocrinol Metab 2015;308:E699-712.

33. Fernandez-Solà J, Preedy VR, Lang CH, et al. Molecular and cellular events in alcohol-induced muscle disease. Alcohol Clin Exp Res 2007;31:1953-62.

34. Bradley JM, Wilson JJ, Hayes K, et al. Sedentary behaviour and physical activity in bronchiectasis: a crosssectional study. BMC Pulm Med 2015;15:61.
35. Garcia-Aymerich J, Félez MA, Escarrabill J, et al. Physical activity and its determinants in severe chronic obstructive pulmonary disease. Med Sci Sports Exerc 2004;36:1667-73.

36. Savi D, Simmonds N, Di Paolo M, et al. Relationship between pulmonary exacerbations and daily physical activity in adults with cystic fibrosis. BMC Pulm Med 2015;15:151.

37. Gimeno-Santos E, Frei A, Steurer-Stey C, et al. Determinants and outcomes of physical activity in patients with COPD: a systematic review. Thorax 2014;69:731-9.

38. Bahmer T, Kirsten AM, Waschki B, et al. Prognosis and longitudinal changes of physical activity in idiopathic pulmonary fibrosis. BMC Pulm Med 2017;17:104.

39. Laveneziana P, Palange P, ERS Research Seminar Faculty. Physical activity, nutritional status and systemic inflammation in COPD. Eur Respir J 2012;40:522-9.

40. Chambaneau A, Filaire M, Jubert L, et al. Nutritional intake, physical activity and quality of life in COPD Patients. Int J Sports Med 2016;37:730-7.

41. van de Bool C, Mattijssen-Verdonschot C, van Melick PP, et al. Quality of dietary intake in relation to body composition in patients with chronic obstructive pulmonary disease eligible for pulmonary rehabilitation. Eur J Clin Nutr 2014;68:159-65.

42. Zemanick ET, Daines CL, Dellon EP, et al. Highlights from the 2016 North American Cystic Fibrosis Conference. Pediatr Pulmonol 2017;52:1103-10.

43. Cranganu A, Camporeale J. Nutrition aspects of lung cancer. Nutr Clin Pract 2009;24:688-700.

44. Koehler F, Doehner W, Hoerning S, et al. Anorexia in chronic obstructive pulmonary disease. Association to cachexia and hormonal derangement. Int J Cardiol 2007;119:83-9.

45. Linkson L, Macedo P, Perrin FM, et al. Anorexia nervosa in cystic fibrosis. Paediatr Respir Rev 2018;26:24-6.

46. Argilés JM, López-Soriano FJ, Busquets S. Mechanisms and treatment of cancer cachexia. Nutr Metab Cardiovasc Dis 2013;23:S19-24.

47. Geary N. Sex differences in disease anorexia. Nutrition 2001;17:499-507.

48. Esposito A, Criscitiello C, Gelao L, et al. Mechanisms of anorexia-cachexia syndrome and rational for treatment with selective ghrelin receptor agonist. Cancer Treat Rev 2015;41:793-7.

49. Cao DX, Wu GH, Zhang B, et al. Resting energy expenditure and body composition in patients with newly detected cancer. Clin Nutr 2010;29:72-7.

50. Dorlöchter L, Røksund O, Helgheim V, et al. Resting 
energy expenditure and lung disease in cystic fibrosis. J Cyst Fibros 2002;1:131-6.

51. Fitting JW, Frascarolo P, Jéquier E, et al. Resting energy expenditure in interstitial lung disease. Am Rev Respir Dis 1990;142:631-5.

52. Schols AM, Soeters PB, Mostert R, et al. Energy balance in chronic obstructive pulmonary disease. Am Rev Respir Dis 1991;143:1248-52.

53. Flores EA, Bristain BR, Pomposelli JJ, et al. Infusion of tumor necrosis factor /cachectin promotes muscle metabolism in the rat. J Clin Invest 1989;83:1614-22.

54. Hall-Angerås $M$, Angeras U, Zamir O, et al. Interaction between corticosterone and tumor necrosis factor simulated protein breakdown in rat skeletal muscle similar to sepsis. Surgery 1990;108:460-6.

55. Chalmers JD, Smith MP, McHugh BJ, et al. Short- and long-term antibiotic treatment reduces airway and systemic inflammation in non-cystic fibrosis bronchiectasis. Am J Respir Crit Care Med 2012;186:657-65.

56. Barreiro E, Schols AM, Polkey MI, et al. Cytokine profile in quadriceps muscles of patients with severe COPD. Thorax 2008;63:100-7.

57. Di Francia M, Barbier D, Mege JL, et al. Tumor necrosis factor-alpha levels and weight loss in chronic obstructive pulmonary disease. Am J Respir Crit Care Med 1994;150:1453-5.

58. Gan WQ, Man SF, Senthilselvan A, et al. Association between chronic obstructive pulmonary disease and systemic inflammation: a systematic review and a metaanalysis. Thorax 2004;59:574-80.

59. Meltzer EB, Noble PW. Idiopathic pulmonary fibrosis. Orphanet J Rare Dis 2008;3:8.

60. Collard HR, Calfee CS, Wolters PJ, et al. Plasma biomarker profiles in acute exacerbation of idiopathic pulmonary fibrosis. Am J Physiol Lung Cell Mol Physiol 2010;299:L3-7.

61. Núñez B, Sauleda J, Garcia-Aymerich J, et al. Lack of correlation between pulmonary and systemic inflammation markers in patients with Chronic Obstructive Pulmonary Disease: A Simultaneous, Two-Compartmental Analysis. Arch Bronconeumol 2016;52:361-7.

62. Munck A. Cystic fibrosis: evidence for gut inflammation. Int J Biochem Cell Biol 2014;52:180-3.

63. Alifano M, Mansuet-Lupo A, Lococo F, et al. Systemic inflammation, nutritional status and tumor immune microenvironment determine outcome of resected nonsmall cell lung cancer. PLoS One 2014;9:e106914.

64. Beckman JS, Koppenol WH. Nitric oxide, superoxide, and peroxynitrite: the good, the bad, and the ugly. Am J Physiol 1996;271:C1424-37.

65. Stamler JS, Meissner G. Physiology of nitric oxide in skeletal muscle. Physiol Rev 2001;81:209-37.

66. Barreiro E, Fermoselle C, Mateu-Jimenez M, et al. Oxidative stress and inflammation in the normal airways and blood of patients with lung cancer and COPD. Free Radic Biol Med 2013;65:859-71.

67. Matsuzawa Y, Kawashima T, Kuwabara R, et al. Change in serum marker of oxidative stress in the progression of idiopathic pulmonary fibrosis. Pulm Pharmacol Ther 2015;32:1-6.

68. Deboeck G, Moraine JJ, Naeije R. Respiratory muscle strength may explain hypoxia-induced decrease in vital capacity. Med Sci Sports Exerc 2005;37:754-8.

69. Romer LM, Haverkamp HC, Amann M, et al. Effect of acute severe hypoxia on peripheral fatigue and endurance capacity in healthy humans. Am J Physiol Regul Integr Comp Physiol 2007;292:R598-606.

70. Brunelle JK, Chandel NS. Oxygen deprivation induced cell death: an update. Apoptosis 2002;7:475-82.

71. Gonzalez NC, Wood JG. Alveolar hypoxia-induced systemic inflammation: what low PO2 does and does not do. Adv Exp Med Biol 2010;662:27-32.

72. Pastoris O, Dossena M, Foppa P, et al. Modifications by chronic intermittent hypoxia and drug treatment on skeletal muscle metabolism. Neurochem Res 1995;20:143-50.

73. Raguso CA, Luthy C. Nutritional status in chronic obstructive pulmonary dis-ease: Role of hypoxia. Nutrition 2011;27:138-43.

74. Rafferty GF, Lou Harris M, Polkey MI, et al. Effect of hypercapnia on maximal voluntary ventilation and diaphragm fatigue in normal humans. Am J Respir Crit Care Med 1999;160:1567-71.

75. England BK, Chastain JL, Mitch WE. Abnormalities in protein synthesis and degradation induced by extracellular $\mathrm{pH}$ in BC3H1 myocytes. Am J Physiol 1991;260:C277-82.

76. Jaitovich A, Angulo M, Lecuona E, et al. High CO2 levels cause skeletal muscle atrophy via AMP-activated kinase (AMPK), FoxO3a protein, and muscle-specific Ring finger protein 1 (MuRF1). J Biol Chem 2015;290:9183-94.

77. Laghi F, Langbein WE, Antonescu-Turcu A, et al. Respiratory and skeletal muscles in hypogonadal men with chronic obstructive pulmonary disease. Am J Respir Crit Care Med 2005;171:598-605.

78. Creutzberg EC, Casaburi R. Endocrinological disturbances in chronic obstructive pulmonary disease. Eur Respir J Suppl 2003;46:76s-80s. 
79. Cazzola M, Rogliani P, Calzetta L, et al. Targeting mechanisms linking COPD to type 2 diabetes mellitus. Trends Pharmacol Sci 2017;38:940-51.

80. Wells CE, Baker EH. Metabolic syndrome and diabetes mellitus in COPD. In: Rabe KF, Wedzicha JA, Wouters EF. editors. COPD and Comorbidity. Sheffield: European Respiratory Society, 2013:117-34.

81. Durieu I, Josserand RN. Cystic fibrosis in 2008. Rev Med Interne 2008;29:901-7.

82. Kuo MC, Lin SH, Lin CH, et al. Type 2 diabetes: an independent risk factor for tuberculosis: a nationwide population-based study. PLoS One 2013;8:e78924.

83. Enomoto T, Usuki J, Azuma A, et al. Diabetes mellitus may increase risk for idiopathic pulmonary fibrosis. Chest 2003;123:2007-11.

84. Gribbin J, Hubbard R, Smith C. Role of diabetes mellitus and gastro-oesophageal reflux in the aetiology of idiopathic pulmonary fibrosis. Respir Med 2009;103:927-31.

85. Bianchi L, Volpato S. Muscle dysfunction in type 2 diabetes: a major threat to patient's mobility and independence. Acta Diabetol 2016;53:879-89.

86. Kanaji N, Watanabe N, Kita N, et al. Paraneoplastic syndromes associated with lung cancer. World J Clin Oncol 2014;5:197-223.

87. Aasebø U, Bremnes RM, de Jong FH, et al. Pituitarygonadal dysfunction in male patients with lung cancer. Association with serum inhibin levels. Acta Oncol 1994;33:177-80.

88. Chalmers JD, McHugh BJ, Docherty C, et al. Vitamin-D deficiency is associated with chronic bacterial colonisation and disease severity in bronchiectasis. Thorax 2013;68:39-47.

89. Janssens W, Bouillon R, Claes B, et al. Vitamin D deficiency is highly prevalent in COPD and correlates with variants in the vitamin D-binding gene. Thorax 2010;65:215-20.

90. Marcondes NA, Raimundo FV, Vanacor R, et al. Hypovitaminosis D in patients with cystic fibrosis: a crosssection study in South Brazil. Clin Respir J 2014;8:455-9.

91. Pazdiora P, Svobodova S, Fuchsova R, et al. Vitamin D in colorectal, breast, prostate and lung cancer: a pilot study. Anticancer Res 2011;31:3619-21.

92. Grey V, Atkinson S, Drury D, et al. Prevalence of low bone mass and deficiencies of vitamins $\mathrm{D}$ and $\mathrm{K}$ in pediatric patients with cystic fibrosis from 3 Canadian centers. Pediatrics 2008;122:1014-20.

93. Hoffer LJ, Robitaille L, Swinton N, et al. Appropriate vitamin $\mathrm{D}$ loading regimen for patients with advanced lung cancer. Nutr J 2016;15:84.

94. Hagaman JT, Panos RJ, McCormack FX, et al. Vitamin D deficiency and reduced lung function in connective tissueassociated interstitial lung diseases. Chest 2011;139:353-60.

95. Elnady HG, EL-Alameey IR, Kamel TB, et al. Predictors of reduced serum vitamin D levels among Egyptian children with interstitial lung disease. J Arab Soc Med Res 2014;9:67-74.

96. Ramnath N, Kim S, Christensen PJ. Vitamin D and lung cancer. Expert Rev Respir Med 2011;5:305-9.

97. Shi Y, Liu T, Yao L, et al. Chronic vitamin D deficiency induces lung fibrosis through activation of the reninangiotensin system. Sci Rep 2017;7:3312.

98. Goldberg AL, Goodman H. Relationship between cortisone and muscle work in determining muscle size. J Physiol 1969;200:667-75.

99. Decramer M, deBock V, Dom R. Functional and histologic picture of steroid-induced myopathy in chronic obstructive pulmonary disease. Am J Respir Crit Care Med 1996;153:1958-64.

100. Hasselgren PO, Alamdari N, Aversa Z, et al. Corticosteroids and muscle wasting: Role of transcription factors, nuclear cofactors, and hyperacetylation. Curr Opin Clin Nutr Metab Care 2010;13:423-8.

101. Schakman O, Gilson H, Kalista S, et al. Mechanisms of muscle atrophy induced by glucocorticoids. Horm Res 2009;72:36-41.

102.Puig-Vilanova E, Rodriguez DA, Lloreta J, et al. Oxidative stress, redox signaling pathways, and autophagy in cachectic muscles of male patients with advanced COPD and lung cancer. Free Radic Biol Med 2015;79:91-108.

103. Rehn TA, Munkvik M, Lunde PK, et al. Intrinsic skeletal muscle alterations in chronic heart failure patients: a diseas-especific myopathy or a result of deconditioning? Heart Fail Rev 2012;17:421-36.

104. Gea J, Estirado C, Barreiro E. Nutritional abnormalities in COPD patients. BRN Rev 2017;3:56-71.

105. Vermeeren MA, Creutzberg EC, Schols AM, et al. Prevalence of nutritional depletion in a large outpatient population of patients with COPD. Respir Med 2006;100:1349-55.

106. Wan ES, Cho MH, Boutaoui N, et al. Genome-wide association analysis of body mass in chronic obstructive pulmonary disease. Am J Respir Cell Mol Biol 2011;45:304-10.

107. Balcells E, Antó JM, Gea J, et al. Characteristics of patients admitted for the first time for COPD exacerbation. Respir Med 2009;103:1293-302. 
108.Ausín P, Martinez-Llorens J, Sabate-Bresco M, et al. Sex differences in function and structure of the quadriceps muscle in COPD patients. Chron Respir Dis 2017;14:127-39.

109. Miravitlles M, Soler-Cataluña JJ, Calle M, et al. Spanish guideline for COPD (GesEPOC). Update 2014. Arch Bronconeumol 2014;50:1-16.

110. Celli BR, Cote CG, Marin JM, et al. The body-mass index, airflow obstruction, dyspnea, and exercise capacity index in chronic obstructive pulmonary disease. N Engl J Med 2004;350:1005-12.

111. Clark CJ, Cochrane LM, Mackay E, et al. Skeletal muscle strength and endurance in patients with mild COPD and the effects of weight training. Eur Respir J 2000;15:92-7.

112.Polkey MI, Kyroussis D, Hamnegard CH, et al. Diaphragm strength in chronic obstructive pulmonary disease. Am J Respir Crit Care Med 1996;154:1310-7.

113.Seymour JM, Spruit MA, Hopkinson NS, et al. The prevalence of quadriceps weakness in COPD and the relationship with disease severity. Eur Respir J 2010;36:81-8.

114. Vilaró J, Ramirez-Sarmiento A, Martínez-Llorens JM, et al. Global muscle dysfunction as a risk factor of readmission to hospital due to COPD exacerbations. Respir Med 2010;104:1896-902.

115. Duckers JM, Shale DJ, Stockley RA, et al. Cardiovascular and musculskeletal co-morbidities in patients with alpha 1 antitrypsin deficiency. Respir Res 2010;11:173.

116.Piitulainen E, Areberg J, Linden M, et al. Nutritional status and muscle strength in patients with emphysema and severe alpha(1)-antitrypsin deficiency. Chest 2002;122:1240-6.

117. Vozoris NT, O’Donnell DE. Prevalence, risk factors, activity limitation and health care utilization of an obese, population-based sample with chronic obstructive pulmonary disease. Can Respir J 2012;19:e18-24.

118. Peltz G, Aguirre MT, Sanderson M, et al. The role of fat mass index in determining obesity. Am J Hum Biol 2010;22:639-47.

119. Lambert AA, Putcha N, Drummond MB, et al. Obesity is associated with increased morbidity in moderate to severe COPD. Chest 2017;151:68-77.

120.Guo Y, Zhang T, Wang Z, et al. Body mass index and mortality in chronic obstructive pulmonary disease: A dose-response meta-analysis. Medicine (Baltimore) 2016;95:e4225.

121. Stoll P, Foerster S, Virchow JC, et al. Overweight is a predictor of long-term survival in hospitalised patients with exacerbations of COPD. Respir Med 2016;116:59-62 .

122. Martínez-García MÁ, de la Rosa-Carrillo D.

Bronchiectasis: Rising from its own ashes. Arch Bronconeumol 2018;54:59-60.

123. Vendrell M, de Gracia J, Olveira C, et al. Diagnosis and treatment of bronchiectasis. Spanish Society of Pneumology and Thoracic Surgery. Arch Bronconeumol 2008;44:629-40.

124. Pasteur MC, Bilton D, Hill AT, et al. British Thoracic Society guideline for non-CF bronchiectasis. Thorax 2010;65:i1-58.

125. Olveira C, Padilla A, Martínez-García MA, et al. Etiology of bronchiectasis in a cohort of 2047 patients. An analysis of the Spanish Historical Bronchiectasis Registry. Arch Bronconeumol 2017;53:366-74.

126. Gale NS, Bolton CE, Duckers JM, et al. Systemic comorbidities in bronchiectasis. Chron Respir Dis 2012;9:231-8.

127. Patel IS, Vlahos I, Wilkinson TM, et al. Bronchiectasis, exacerbation indices, and inflammation in chronic obstructive pulmonary disease. Am J Respir Crit Care Med 2004;170:400-7.

128. Murray MP, Pentland JL, Hill AT. A randomised crossover trial of chest physiotherapy in non-cystic fibrosis bronchiectasis. Eur Respir J 2009;34:1086-92.

129. Moran F, Piper A, Elborn JS, et al. Respiratory muscle pressures in non-CF bronchiectasis: repeatability and reliability. Chron Respir Dis 2010;7:165-71.

130. Balañá A, Martínez-Llorens J, Rodríguez DA, et al. Skeletal muscle function and structure in patients with non-cystic fibrosis bronchiectasis. Eur Respir J 2016;48:OA265.

131. Ozalp O, Inal-Ince D, Calik E, et al. Extrapulmonary features of bronchiectasis: muscle function, exercise capacity, fatigue, and health status. Multidiscip Respir Med 2012;7:3.

132. Sharma R, Florea VG, Bolger AP, et al. Wasting as an independent predictor of mortality in patients with cystic fibrosis. Thorax 2001;56:746-50.

133. Pinet C, Cassart M, Scillia P, et al. Function and bulk of respiratory and limb muscles in patients with cystic fibrosis. Am J Respir Crit Care Med 2003;168:989-94.

134.Hussey J, Gormley J, Leen G, et al. Peripheral muscle strength in young males with cystic fibrosis. J Cyst Fibros 2002;1:116-21.

135. Burtin C, Hebestreit H. Rehabilitation in patients with chronic respiratory disease other than chronic obstructive pulmonary disease: exercise and physical activity 
interventions in cystic fibrosis and non-cystic fibrosis bronchiectasis. Respiration 2015;89:181-9.

136. Barry SC, Gallagher CG. Corticosteroids and skeletal muscle function in cystic fibrosis. J Appl Physiol (1985) 2003;95:1379-84.

137. Hebestreit H, Kieser S, Rudiger S, et al. Physical activity is independently related to aerobic capacity in cystic fibrosis. Eur Respir J 2006;28:734-9.

138. Ionescu AA, Nixon LS, Luzio S, et al. Pulmonary function, body composition, and protein catabolism in adults with cystic fibrosis. Am J Respir Crit Care Med 2002;165:495-500.

139. Richeldi L, Collard HR, Jones MG. Idiopathic pulmonary fibrosis. Lancet 2017;389:1941-52.

140. Kurashima K, Takayanagi N, Tsuchiya N, et al. The effect of emphysema on lung function and survival in patients with idiopathic pulmonary fibrosis. Respirology 2010;15:843-8.

141. Ryerson CJ, Hartman T, Elicker BM, et al. Clinical features and outcomes in combined pulmonary fibrosis and emphysema in idiopathic pulmonary fibrosis. Chest 2013;144:234-40.

142. Chailleux E, Fauroux B, Binet F, et al. Predictors of survival in patients receiving domiciliary oxygen therapy or mechanical ventilation. A 10- year analysis of ANTADIR observatory. Chest 1996;109:741-9.

143. Schwebel C, Pin I, Barnoud D, et al. Prevalence and consequences of nutritional depletion in lung transplant candidates. Eur Respir J 2000;16:1050-5.

144. Madill J, Maurer JR, de Hoyos A. A comparison of preoperative and postoperative nutritional states of lung transplant recipients. Transplantation 1993;56:347-50.

145.Kozu R, Jenkins S, Senjyu H. Evaluation of activity limitation in patients with idiopathic pulmonary fibrosis grouped according to Medical Research Council dyspnea grade. Arch Phys Med Rehabil 2014;95:950-5.

146.Jackson RM, Gómez-Marín OW, Ramos CF, et al. Exercise limitation in IPF patients: a randomized trial of pulmonary rehabilitation. Lung 2014;192:367-76.

147. Nishiyama O, Taniguchi H, Kondoh Y, et al. Quadriceps weakness is related to exercise capacity in idiopathic pulmonary fibrosis. Chest 2005;127:2028-33.

148. Kozu R, Senjyu H, Jenkins SC, et al. Differences in response to pulmonary rehabilitation in idiopathic pulmonary fibrosis and chronic obstructive pulmonary disease. Respiration 2011;81:196-205.

149. Mori S, Usami N, Fukumoto K, et al. The significance of the prognostic nutritional index in patients with completely resected non-small cell lung cancer. PLoS One 2015;10:e0136897.

150. Collins J, Noble S, Chester J, et al. The assessment and impact of sarcopenia in lung cancer: a systematic literature review. BMJ Open 2014;4:e003697.

151. Cykert S, Kissling G, Hansen CJ. Patient preferences regarding possible outcomes of lung resection: what outcomes should preoperative evaluations target? Chest 2000;117:1551-9.

152.Johns N, Stephens NA, Fearon KC. Muscle wasting in cancer. Int J Biochem Cell Biol 2013;45:2215-29.

153. Jones LW, Peddle CJ, Eves ND, et al. Effects of presurgical exercise training on cardiorespiratory fitness among patients undergoing thoracic surgery for malignant lung lesions. Cancer 2007;110:590-8.

154. Stephens NA, Gray C, MacDonald AJ, et al. Sexual dimorphism modulates the impact of cancer cachexia on lower limb muscle mass and function. Clin Nutr 2012;31:499-505.

155. Tsukioka T, Nishiyama N, Izumi N, et al. Sarcopenia is a novel poor prognostic factor in male patients with pathological Stage I non-small cell lung cancer. Jpn J Clin Oncol 2017;47:363-8.

156. Wilcock A, Maddocks M, Lewis M, et al. Use of a cybex norm dynamometer to assess muscle function in patients with thoracic cancer. BMC Palliat Care 2008;7:3.

157. Chevari S, Andial T, Benke K, et al. Free radical reactions and cancer. Vopr Med Khim 1992;38:4-5.

158. Gomes-Marcondes MC, Tisdale MJ. Induction of protein catabolism and the ubiquitin-proteasome pathway by mild oxidative stress. Cancer Lett 2002;180:69-74.

159. Schulkes KJ, Hamaker ME, van den Bos F, et al. Relevance of a geriatric assessment for elderly patients with lung cancer-A Systematic Review. Clin Lung Cancer 2016;17:341-9.e3.

160. Quoix, E. Zalcman G, Oster JP, et al. Carboplatin and weekly paclitaxel doublet chemotherapy compared with monotherapy in elderly patients with advanced non-smallcell lung cancer: IFCT-0501 randomised, phase 3 trial. Lancet 2011;378:1079-88.

161. Cudennec T, Gendry T, Labrune S, et al. Use of a simplified geriatric evaluation in thoracic oncology. Lung Cancer 2010;67:232-6.

162. Borget I, Corre R, Le Caer H et al, Impact of a comprehensive geriatric assessment on management of strategies in elderly patients with advanced no small cell lung cancer (NSCLC): a polled analysis of two phase 2 prospective study of the GFPC group. J Thorac Oncol 
2013;8:S1175-6.

163. Cheng HB, To T, Joshi R, et al. Outcomes of geriatric assessment for older lung cancer patients from a dedicated geriatric oncology program. J Thorac Oncol 2011;6:S1221-2.

164. Everitt S, Krishnasamy M, Duffy M, et al. Utilising evidence to inform acute toxicity scoring for patients receiving radiation therapy for lung cancer. Aust J Cancer Nurs 2011;12:4-9.

165.McCallum PD. Nutrition Screening and Assessment in Oncology. In: Elliot L, Molseed L, McCallum PD, editors. The Clinical Guide to Oncology Nutrition (2nd ed.). Chicago: The American Dietetic Association, 2006:44-53.

166. Kiss NK, Krishnasamy M, Isenring EA. The effect of nutrition intervention in lung cancer patients undergoing chemotherapy and/or radiotherapy: a systematic review. Nutr Cancer 2014;66:47-56.

167.Hill AT, Campbell EJ, Hill SL et al. Association between airway bacterial load and markers of airway inflammation in patients with stable chronic bronchitis. Am J Med 2000;109:288-95.

168. Barreiro E, Gea J. Amino Acid and Protein Metabolism in Pulmonary Diseases and Nutritional Abnormalities: A Special Focus on Chronic Obstructive Pulmonary Disease. Chapter 12. In: Dardevet D. editor. The molecular nutrition of amino acids and proteins. Elsevier, 2016:145-59.

169. Vermeeren MA, Schols AM, Wouters EF. Effects of an acute exacerbation on nutritional and metabolic profile of patients with COPD. Eur Respir J 1997;10:2264-9.

170.Pitta F, Troosters T, Probst VS, et al. Physical activity and hospitalization for exacerbation of COPD. Chest 2006;129:536-44.

171. Ansari K, Keaney N, Taylor I, et al. Muscle weakness, health status and frequency of exacerbations in chronic obstructive pulmonary disease. Postgrad Med J 2012;88:372-6.

172. Neves PC, Guerra M, Ponce P, et al. Non-cystic fibrosis bronchiectasis. Interact Cardiovasc Thorac Surg 2011;13:619-25.

173. Bhatt JM. Treatment of pulmonary exacerbations in cystic fibrosis. Eur Respir Rev 2013;22:205-16.

174. Wieboldt J, Atallah L, Kelly JL, et al. Effect of acute exacerbations on skeletal muscle strength and physical activity in cystic fibrosis. J Cyst Fibros 2012;11:209-15.

175. Burtin C, Van RH, Vrijsen B, et al. Impact of exacerbations of cystic fibrosis on muscle strength. Respir Res 2013;14:46.

176.Kim HJ, Perlman D, Tomic R. Natural history of idiopathic pulmonary fibrosis. Respir Med 2015;109:661-70.

177. Mahan LK, Escott-Stump S. editors. Krause's Food, Nutrition, \& Diet Therapy. 10th ed. Philadelphia: W.B. Saunders, 2000:970-86.

178. World Health Organization (WHO). BMI classification [accesed in February 2018]. Available online: http://apps. who.int/bmi/index.jsp?introPage=intro_3.html

179. Schols AM, Wouters EF, Soeters PB, et al. Body composition by bioelectrical-impedance analysis compared with deuterium dilution and skin-fold anthropometry in patients with chronic obstructive pulmonary disease. Am J Clin Nutr 1991;53:421-4.

180. Coin A, Sergi G, Minicuci N, et al. Fat-free mass and fat mass reference values by dual-energy $\mathrm{X}$-ray absorptiometry (DEXA) in a 20-80 year-old Italian population. Clin Nutr 2008;27:87-94.

181. Argilés JM, López-Soriano FJ, Toledo M, et al. The cachexia score (CASCO): a new tool for staging cachectic cancer patients. J Cachexia Sarcopenia Muscle 2011;2:87-93.

182. Argilés JM, Betancourt A, Guàrdia-Olmos J, et al. Validation of the CAchexia SCOre (CASCO). Staging cancer patients: The use of miniCASCO as a simplified tool. Front Physiol 2017;8:92.

183. Orozco-Levi M, Gayete A, Rodríguez C, et al. Noninvasive functional evaluation of the reserve in fatigue and the diaphragm structure using transthoracic echography in B and M modes. Arch Bronconeumol 2010;46:571-9.

184. Scheibe N, Sosnowski N, Pinkhasik A, et al. Sonographic evaluation of diaphragmatic dysfunction in COPD patients. Int J Chron Obstruct Pulmon Dis 2015;10:1925-30.

185.Lechtzin N, Wiener CM, Shade DM, et al. Spirometry in the supine position improves the detection of diaphragmatic weakness in patients with amyotrophic lateral sclerosis. Chest 2002;121:436-42.

186. Black LF, Hyatt RE. Maximal respiratory pressures: normal values and relationship to age and sex. Am Rev Respir Dis 1969;99:696-702.

187. Morales P, Sanchis J, Cordero PJ, et al. Maximum static respiratory pressures in adults. The reference values for a Mediterranean Caucasian population. Arch Bronconeumol 1997;33:213-9.

188. Polkey MI, Green M, Moxham J. Measurement of respiratory muscle strength. Thorax 1995;50:1131-5.

189. Héritier F, Rahm F, Pasche P, et al. Sniff nasal inspiratory pressure. A noninvasive assessment of inspiratory muscle strength. Am J Respir Crit Care Med 1994;150:1678-83.

190.Martínez-Llorens J, Ausín P, Roig A, et al. Nasal inspiratory pressure: an alternative for the assessment 
of inspiratory muscle strength? Arch Bronconeumol 2011;47:169-75.

191.Araújo PR, Resqueti VR, Nascimento Junior J, et al. Reference values for sniff nasal inspiratory pressure in healthy subjects in Brazil: a multicenter study. J Bras Pneumol 2012;38:700-7.

192. Kamide N, Ogino M, Yamashina N, et al. Sniff nasal inspiratory pressure in healthy Japanese subjects: mean values and lower limits of normal. Respiration 2009;77:58-62.

193. Cherniack RM, Farhi LE, Armstrong BW, et al. A comparison of esophageal and intrapleural pressure in man. J Appl Physiol 1955;8:203-11.

194.Laroche CM, Mier AK, Moxham J, et al. The value of sniff esophageal pressures in the assessment of global inspiratory muscle strength. Am Rev Respir Dis 1988;138:598-603.

195.Laporta D, Grassino A. Assessment of transdiaphragmatic pressure in humans. J Appl Physiol (1985) 1985;58:1469-76.

196. Mier A, Brophy C, Moxham J, et al. Twitch pressures in the assessment of diaphragm weakness. Thorax 1989;44:990-6.

197. Mills GH, Kyroussis D, Hamnegard CH, et al. Unilateral magnetic stimulation of the phrenic nerve. Thorax 1995;50:1162-72.

198. Polkey MI, Harris ML, Hughes PD, et al. The contractile properties of the elderly human diaphragm. Am J Respir Crit Care Med 1997;155:1560-4.

199.Wragg S, Aquilina R, Moran J, et al. Comparison of cervical magnetic stimulation and bilateral percutaneous electrical stimulation of the phrenic nerves in normal subjects. Eur Respir J 1994;7:1788-92.

200. Ramírez-Sarmiento A, Orozco-Levi M, Barreiro E, et al. Expiratory muscle endurance in chronic obstructive pulmonary disease. Thorax 2002;57:132-6.

201.Ramirez-Sarmiento A, Orozco-Levi M, Guell R, et al. Inspiratory muscle training in patients with chronic obstructive pulmonary disease: structural adaptation and physiologic outcomes. Am J Respir Crit Care Med 2002;166:1491-7.

202.Larson JL, Covey MK, Berry J, et al. Discontinuous incremental threshold loading test: measure of respiratory muscle endurance in patients with COPD. Chest 1999;115:60-7.

203. Martyn JB, Moreno RH, Paré PD, et al. Measurement of inspiratory muscle performance with incremental threshold loading. Am Rev Respir Dis 1987;135:919-23.

204.Hamilton AL, Killian KJ, Summers E, et al. Muscle strength, symptom intensity, and exercise capacity in patients with cardiorespiratory disorders. Am J Respir Crit Care Med 1995;152:2021-31.

205. Killian KJ, Summers E, Jones NL, et al. Dyspnea and leg effort during incremental cycle ergometry. Am Rev Respir Dis 1992;145:1339-45.

206. Beauchamp MK, Sibley KM, Lakhani B, et al. Impairments in systems underlying control of balance in COPD. Chest 2012;141:1496-503.

207.Malaguti C, Napolis LM, Villaça D, et al. Relationship between peripheral muscle structure and function in patients with chronic obstructive pulmonary disease with different nutritional status. J Strength Cond Res 2011;25:1795-803.

208. Bohannon RW. Reference values for extremity muscle strength obtained by hand-held dynamometry from adults aged 20 to 79 years. Arch Phys Med Rehabil 1997;78:26-32.

209.Luna-Heredia E, Martín-Peña G, Ruiz-Galiana J. Handgrip dynamometry in healthy adults. Clin Nutr 2005;24:250-8.

210.Hurley MV, Rees J, Newham DJ. Quadriceps function, proprioceptive acuity and functional performance in healthy young, middle-aged and elderly subjects. Age Ageing 1998;27:55-62.

211. Neder JA, Nery LE, Shinzato GT, et al. Reference values for concentric knee isokinetic strength and power in nonathletic men and women from 20 to 80 years old. J Orthop Sports Phys Ther 1999;29:116-26.

212. Nellessen AG, Donária L, Hernandes NA, et al. Analysis of three different equations for predicting quadriceps femoris muscle strength in patients with COPD. J Bras Pneumol 2015;41:305-12.

213. Webb AR, Newman LA, Taylor M, et al. Hand grip dynamometry as a predictor of postoperative complications reappraisal using age standardized grip strengths. JPEN J Parenter Enteral Nutr 1989;13:30-3.

214. Russell DM, Leiter LA, Whitwell J, et al. Skeletal muscle function during hypocaloric diets and fasting: a comparison with standard nutritional assessment parameters. Am J Clin Nutr 1983;37:133-8.

215.Beretta-Piccoli M, D'Antona G, Barbero M, et al. Evaluation of central and peripheral fatigue in the quadriceps using fractal dimension and conduction velocity in young females. PLoS One 2015;10:e0123921.

216. Polkey MI, Kyroussis D, Hamnegard CH, et al. Quadriceps strength and fatigue assessed by magnetic stimulation of the femoral nerve in man. Muscle Nerve 1996;19:549-55.

217.Hamnegård CH, Sedler M, Polkey MI, et al. Quadriceps 
strength assessed by magnetic stimulation of the femoral nerve in normal subjects. Clin Physiol Funct Imaging 2004;24:276-80.

218. Coronell C, Orozco-Levi M, Méndez R, et al. Relevance of assessing quadriceps endurance in patients with COPD. Eur Respir J 2004;24:129-36.

219. Serres I, Gautier V, Varray A, et al. Impaired skeletal muscle endurance related to physical inactivity and altered lung function in COPD patients. Chest 1998;113:900-5.

220.Van't Hul A, Harlaar J, Gosselink R, et al. Quadriceps muscle endurance in patients with chronic obstructive pulmonary disease. Muscle Nerve 2004;29:267-74.

221. Swallow EB, Gosker HR, Ward KA, et al. A novel technique for nonvolitional assessment of quadriceps muscle endurance in humans. J Appl Physiol (1985) 2007;103:739-46.

222.Preston AM. Cigarette smoking-nutritional implications. Prog Food Nutr Sci 1991;15:183-217.

223. Alkerwi A, Baydarlioglu B, Sauvageot N, et al. Smoking status is inversely associated with overall diet quality: Findings from the ORISCAV-LUX study. Clin Nutr 2017;36:1275-82.

224.Ikonomidis I, Marinou M, Vlastos D, et al. Effects of varenicline and nicotine replacement therapy on arterial elasticity, endothelial glycocalyx and oxidative stress during a 3-month smoking cessation program. Atherosclerosis 2017;262:123-30.

225.Leischow SJ, Stitzer ML. Effects of smoking cessation on caloric intake and weight gain in an inpatient unit. Psychopharmacology 1991;104:522-6.

226. Rodrigues FM, Ramos D, Xavier RF, et al. Nasal and systemic inflammatory profile after short term smoking cessation. Respir Med 2014;108:999-1006.

227. Rom O, Reznick AZ, Keidar Z, et al. Smoking cessationrelated weight gain--beneficial effects on muscle mass, strength and bone health. Addiction 2015;110:326-35.

228. Crawford J. Clinical results in cachexia therapeutics. Curr Opin Clin Nutr Metab Care 2016;19:199-204.

229. Schindler T, Michel S, Wilson AW. Nutrition management of cystic fibrosis in the 21st century. Nutr Clin Pract 2015;30:488-500.

230. Weekes CE, Emery PW, Elia M. Dietary counselling and food fortification in stable COPD: A randomised trial. Thorax 2009;64:326-31.

231. Shukla SD, Budden KF, Neal R, et al. Microbiome effects on immunity, health and disease in the lung. Clin Transl Immunology 2017;6:e133.

232. Varraso R, Willett WC, Camargo CA Jr. Prospective study of dietary fiber and risk of chronic obstructive pulmonary disease among US women and men. Am J Epidemiol 2010;171:776-84.

233. Harvie M. Nutritional supplements and cancer: potential benefits and proven harms. Am Soc Clin Oncol Educ Book 2014:e478-86.

234.Efthimiou J, Fleming J, Gomes C, et al. The effect of supplementary oral nutrition in poorly nourished patients with chronic obstructive pulmonary disease. Am Rev Respir Dis 1988;137:1075-82.

235. Smyth RL, Rayner O. Oral calorie supplements for cystic fibrosis. Cochrane Database Syst Rev 2017;5:CD000406.

236. Fouillet H, Mariotti F, Gaudichon C, et al. Peripheral and splanchnic metabolism of dietary nitrogen are differently affected by the protein source in humans as assessed by compartmental modeling. J Nutr 2002;132:125-33.

237. Weisberg J, Wanger J, Olson J, et al. Megestrol acetate stimulates weight gain and ventilation in underweight COPD patients. Chest 2002;121:1070-8.

238. Garcia-Aymerich J, Lange P, Benet M, et al. Regular physical activity reduces hospital admission and mortality in chronic obstructive pulmonary disease: a population based cohort study. Thorax 2006;61:772-8.

239. Garcia-Aymerich J. Physical activity in Chronic Obstructive Pulmonary Disease. An Update. Arch Bronconeumol 2017;53:413-4.

240.Loprinzi PD, Walker JF. Increased daily movement associates with reduced mortality among COPD patients having systemic inflammation. Int J Clin Pract 2016;70:286-91.

241. Schneiderman JE, Wilkes DL, Atenafu EG, et al. Longitudinal relationship between physical activity and lung health in patients with cystic fibrosis. Eur Respir J 2014;43:817-23.

242.Peddle-McIntyre CJ, Baker MK, Lee YC, et al. The feasibility of a pragmatic distance-based intervention to increase physical activity in lung cancer survivors. Eur J Cancer Care (Engl) 2018;27.

243.Pleguezuelos E, Guirao L, Moreno E, et al. Safety of a rehabilitation program for COPD patients. Arch Bronconeumol 2018;54:111-2.

244. Franssen FM, Broekhuizen R, Janssen PP, et al. Effects of whole-body exercise training on body composition and functional capacity in normal-weight patients with COPD. Chest 2004;125:2021-8.

245. Güell R, Resqueti V, Sangenis M, et al. Impact of pulmonary rehabilitation on psychosocial morbidity in patients with severe COPD. Chest 2006;129:899-904. 
246. Güell Rous MR, Díaz Lobato S, Rodríguez Trigo G, et al. Pulmonary rehabilitation. Sociedad Española de Neumología y Cirugía Torácica (SEPAR). Arch Bronconeumol 2014;50:332-44.

247.Lee AL, Hill CJ, McDonald CF, et al. Pulmonary rehabilitation in individuals with non-cystic fibrosis bronchiectasis: A systematic review. Arch Phys Med Rehabil 2017;98:774-82.e1.

248. Rivas-Perez H, Nana-Sinkam P. Integrating pulmonary rehabilitation into the multidisciplinary management of lung cancer: a review. Respir Med 2015;109:437-42.

249. Spruit MA, Gosselink R, Troosters T, et al. Resistance versus endurance training in patients with COPD and peripheral muscle weakness. Eur Respir J 2002;19:1072-8.

250. Vainshelboim B, Fox BD, Oliveira J, et al. Exercise training in idiopathic pulmonary fibrosis. Expert Rev Respir Med 2016;10:69-77.

251. Maltais F, LeBlanc P, Simard C, et al. Skeletal muscle adaptation to endurance training in patients with chronic obstructive pulmonary disease. Am J Respir Crit Care Med 1996;154:442-7.

252. Watz H, Pitta F, Rochester CL, et al. An official European Respiratory Society statement on physical activity in COPD. Eur Respir J 2014;44:1521-37.

253. Franssen FM, Broekhuizen R, Janssen PP, et al. Limb muscle dysfunction in COPD: effects of muscle wasting and exercise training. Med Sci Sports Exerc 2005;37:2-9.

254. Ortega F, Toral J, Cejudo P, et al. Comparison of effects of strength and endurance training in patients with chronic obstructive pulmonary disease. Am J Respir Crit Care Med 2002;166:669-74.

255. Vogiatzis I, Simoes DC, Stratakos G, et al. Effect of pulmonary rehabilitation on muscle remodelling in cachectic patients with COPD. Eur Respir J 2010;36:301-10.

256. Barreiro E, Rabinovich R, Marin-Corral J, et al. Chronic endurance exercise induces quadriceps nitrosative stress in patients with severe COPD. Thorax 2009;64:13-9.

257. Rodriguez DA, Kalko S, Puig-Vilanova E, et al. Muscle and blood redox status after exercise training in severe COPD patients. Free Radic Biol Med 2012;52:88-94.

258. Bustamante V, López de Santa María E, Gorostiza A, et al. Muscle training with repetitive magnetic stimulation of the quadriceps in severe COPD patients. Respir Med 2010;104:237-45.

259. Maddocks M, Delogu V, Jones SE, et al. Exercise training versus neuromuscular stimulation in severe Chronic Obstructive Pulmonary Disease. Arch Bronconeumol 2017;53:357-9.
260. Sillen MJ, Speksnijder CM, Eterman RM, et al. Effects of neuromuscular electrical stimulation of muscles of ambulation in patients with chronic heart failure or COPD: a systematic review of the English-language literature. Chest 2009;136:44-61.

261. Spruit MA, Singh SJ, Garvey C, et al. An official American Thoracic Society/European Respiratory Society statement: key concepts and advances in pulmonary rehabilitation. Am J Respir Crit Care Med 2013;188:e13-64.

262. Troosters T, Probst VS, Crul T, et al. Resistance training prevents deterioration in quadriceps muscle function during acute exacerbations of chronic obstructive pulmonary disease. Am J Respir Crit Care Med 2010;181:1072-7.

263. Driessen EJ, Peeters ME, Bongers BC, et al. Effects of prehabilitation and rehabilitation including a home-based component on physical fitness, adherence, treatment tolerance, and recovery in patients with non-small cell lung cancer: A systematic review. Crit Rev Oncol Hematol 2017;114:63-76.

264. Gruet M, Brisswalter J, Mely L, et al. Use of the peak heart rate reached during six-minute walk test to predict individualized training intensity in patients with cystic fibrosis: validity and reliability. Arch Phys Med Rehabil 2010;91:602-7.

265.Neder JA, Sword D, Ward SA, et al. Home based neuromuscular electrical stimulation as a new rehabilitative strategy for severely disabled patients with chronic obstructive pulmonary disease (COPD). Thorax 2002;57:333-7.

266.Ebner N, Springer J, Kalantar-Zadeh K, et al. Mechanism and novel therapeutic approaches to wasting in chronic disease. Maturitas 2013;75:199-206.

267. Burdet L, de Muralt B, Schutz Y, et al. Administration of growth hormone to underweight patients with chronic obstructive pulmonary disease. A prospective, randomized, controlled study. Am J Respir Crit Care Med 1997;156:1800-6.

268. Bai Y, Hu Y, Zhao Y, et al. Anamorelin for cancer anorexiacachexia syndrome: a systematic review and meta-analysis. Support Care Cancer 2017;25:1651-9.

269. Nagaya N, Itoh T, Murakami S, et al. Treatment of cachexia with ghrelin in patients with COPD. Chest 2005;128:1187-93.

270. Vermeeren MA, Wouters EF, Geraerts-Keeris AJ, et al. Nutritional support in patients with chronic obstructive pulmonary disease during hospitalization for an acute exacerbation; a randomized controlled feasibility trial. Clin 
Nutr 2004;23:1184-92.

271.Lalmolda C, Coll-Fernández R, Martínez N, et al. Effect of a rehabilitation-based chronic disease management program targeting severe COPD exacerbations on readmission patterns. Int J Chron Obstruct Pulmon Dis 2017;12:2531-8.

272.Kofod LM, Døssing M, Steentoft J, et al. Resistance training with ankle weight cuffs is feasible in patients with acute exacerbation of COPD. J Cardiopulm Rehabil Prev 2017;37:49-56.

273. Assi M, Rébillard A. The Janus-faced role of antioxidants in cancer cachexia: New insights on the established concepts. Oxid Med Cell Longev 2016;2016:9579868.

274. Kandhare AD, Mukherjee A, Ghosh P, et al. Efficacy of

Cite this article as: Gea J, Sancho-Muñoz A, Chalela R. Nutritional status and muscle dysfunction in chronic respiratory diseases: stable phase versus acute exacerbations. J Thorac Dis 2018;10(Suppl 12):S1332-S1354. doi: 10.21037/ jtd.2018.02.66 antioxidant in idiopathic pulmonary fibrosis: A systematic review and meta-analysis. EXCLI J 2016;15:636-51.

275. Rennard SI, Fogarty C, Kelsen S, et al. The safety and efficacy of infliximab in moderate to severe chronic obstructive pulmonary disease. Am J Respir Crit Care Med 2007;175:926-34.

276. Rogliani P, Calzetta L, Ora J, et al. Canakinumab for the treatment of chronic obstructive pulmonary disease. Pulm Pharmacol Ther 2015;31:15-27.

277. Rossman MJ, Garten RS, Groot HJ, et al. Ascorbate infusion increases skeletal muscle fatigue resistance in patients with chronic obstructive pulmonary disease. Am J Physiol Regul Integr Comp Physiol 2013;305:R1163-70. 